Ramasamy, S. (2016), "The Role of Employers and Employer Engagement in Labour Migration from Third Countries to the EU", OECD Social, Employment and Migration Working Papers, No. 178, OECD Publishing, Paris.

http://dx.doi.org/10.1787/5jlwxc0366xr-en
OECD Social, Employment and Migration Working Papers No. 178

\title{
The Role of Employers and Employer Engagement in Labour Migration from Third Countries to the EU
}

\section{Sankar Ramasamy}

JEL Classification: F22, F21, J61

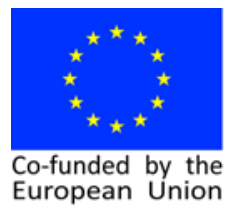


Organisation de Coopération et de Développement Économiques

Organisation for Economic Co-operation and Development

27-May-2016

DIRECTORATE FOR EMPLOYMENT, LABOUR AND SOCIAL AFFAIRS

English - Or. English

EMPLOYMENT, LABOUR AND SOCIAL AFFAIRS COMMITTEE

Cancels \& replaces the same document of 04 May 2016

The Role of Employers and Employer Engagement in Labour Migration from Third Countries to the EU

Sankar Ramasamy (OECD)

JEL Classification: F22, F21, J61

This paper is part of the joint project between the Directorate General for Migration and Home Affairs of the European Commission and the OECD's Directorate for Employment, Labour and Social Affairs on "Review of Labour Migration Policy in Europe".

This document has been produced with the financial assistance of the European Union. The views expressed herein can in no way be taken to reflect the official opinion of the European Union.

Grant: HOME/2013/EIFX/CA/002 / 30-CE-0615920/00-38 (DI130895)

A previous version of this paper DELSA/ELSA/MI(2015)8 was presented and discussed at the OECD Working Party on Migration in June 2015.

Authorised for publication by Stefano Scarpetta, Director, Directorate for Employment, Labour and Social Affairs, OECD.

wWw.oecd.org/els/workingpapers

JT03396789

Complete document available on OLIS in its original format

This document and any map included herein are without prejudice to the status of or sovereignty over any territory, to the delimitation of international frontiers and boundaries and to the name of any territory, city or area. 


\title{
DIRECTORATE FOR EMPLOYMENT, LABOUR AND SOCIAL AFFAIRS
}

\author{
www.oecd.org/els
}

\section{OECD SOCIAL, EMPLOYMENT AND MIGRATION WORKING PAPERS}

\author{
www.oecd.org/els/workingpapers
}

OECD Working Papers should not be reported as representing the official views of the OECD nor of its member countries nor of the members of the European Union. The opinions expressed and arguments employed are those of the author(s).

Working Papers describe preliminary results or research in progress by the author(s) and are published to stimulate discussion on a broad range of issues on which the OECD works. Comments on Working Papers are welcomed, and may be sent to the Directorate for Employment, Labour and Social Affairs OECD, 2 rue André-Pascal, 75775 Paris Cedex 16, France.

This series is designed to make available to a wider readership selected labour market, social policy and migration studies prepared for use within the OECD. Authorship is usually collective, but principal writers are named. The papers are generally available only in their original language - English or French with a summary in the other.

This document and any map included herein are without prejudice to the status of or sovereignty over any territory, to the delimitation of international frontiers and boundaries and to the name of any territory, city or area.

The statistical data for Israel are supplied by and under the responsibility of the relevant Israeli authorities. The use of such data by the OECD is without prejudice to the status of the Golan Heights, East Jerusalem and Israeli settlements in the West Bank under the terms of international law.

\section{Applications for permission to reproduce or translate all or part of this material should be made to:}

\author{
Head of Publications Service \\ OECD \\ 2, rue André-Pascal \\ 75775 Paris, CEDEX 16 \\ France
}

\section{Copyright OECD 2016}




\begin{abstract}
This paper is part of the joint project between the Directorate General for Migration and Home Affairs of the European Commission and the OECD's Directorate for Employment, Labour and Social Affairs on "Review of Labour Migration Policy in Europe".

This document has been produced with the financial assistance of the European Union. The views expressed herein can in no way be taken to reflect the official opinion of the European Union.

Grant: HOME/2013/EIFX/CA/002 / 30-CE-0615920/00-38 (DI130895).

A previous version of this paper DELSA/ELSA/MI(2015)8 was presented and discussed at the OECD working party on migration in June 2015.

The paper examines the ways in which employers are protagonists in international labour migration, and what can be done to ensure that they are partners in increasing European attractiveness for internationally mobile talent. Facilitating movement of Intra-Corporate Transfer (ICT) workers in multinational companies, improving the ability of SMEs to access foreign workers, as well as attracting entrepreneurs and investors in the EU single market, are the three principal channels examined in the report. The paper provides recommendations for policy development in these three areas.
\end{abstract}




\section{TABLE OF CONTENTS}

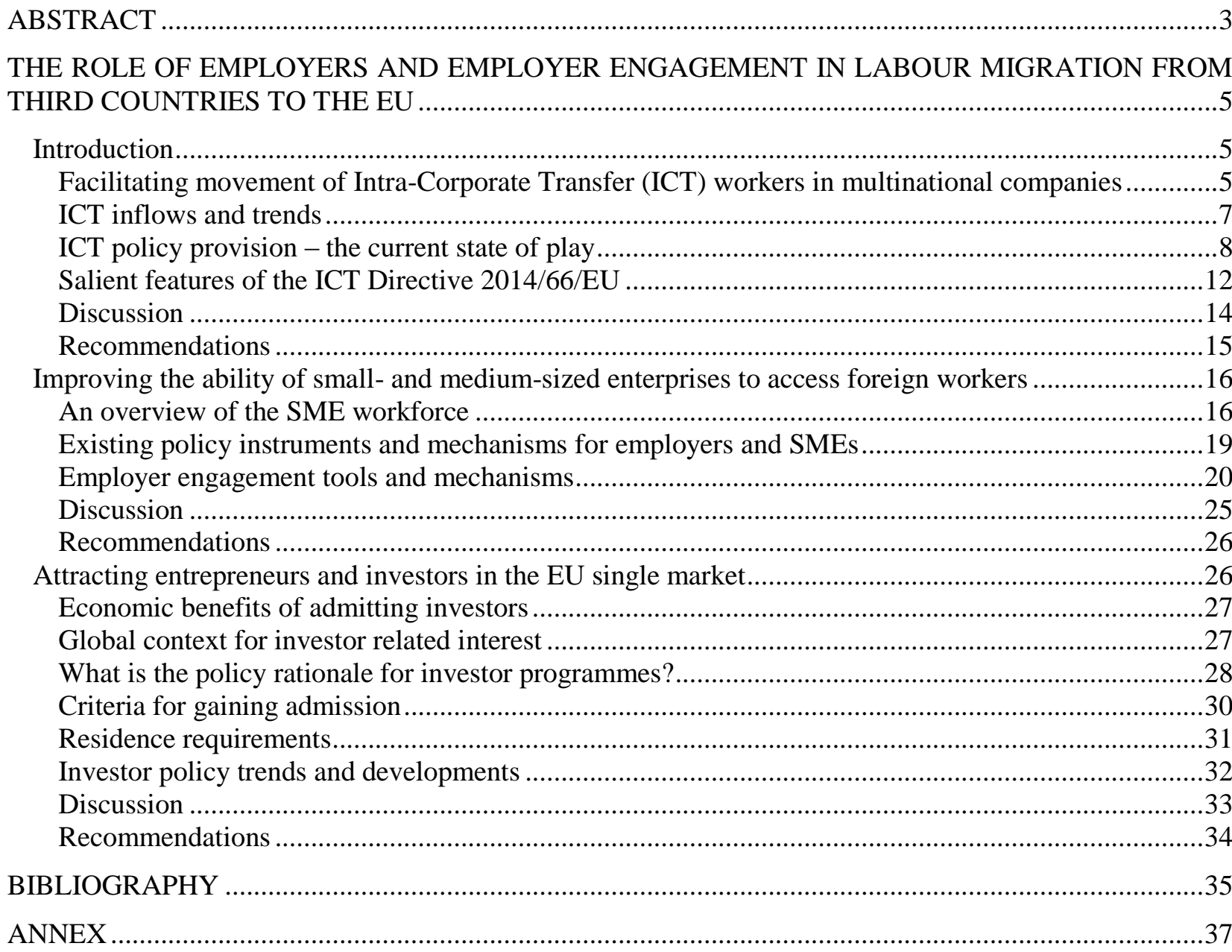

\section{Tables}

Table 1. Workers distribution across firms, by origin, 2012

\section{Figures}

Figure 1. Inflows of Intra-corporate transfers in selected OECD countries, 2007-2012 _...................8

Figure 2. Maximum duration of ICT permits (years) ….............................................................11

Figure 3. Immigration laws prevent your company from employing foreign labour ..........................18

Figure 4. High net worth individual population, 2007-12 (by region) ..............................................28

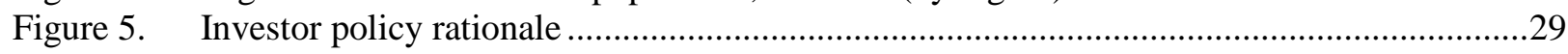

Figure 6. Investment thresholds, Euros, 2015 (log scale) …............................................................ 
DELSA/ELSA/WD/SEM(2016)4

\section{THE ROLE OF EMPLOYERS AND EMPLOYER ENGAGEMENT IN LABOUR MIGRATION FROM THIRD COUNTRIES TO THE EU}

\section{Introduction}

1. The fundamental principle of all labour migration in EU countries is that third-country nationals may come from abroad for work only if they have a valid job offer. The employer who makes this offer is thus the first actor in the process of labour migration, and the state is a gatekeeper only of the flows which are driven by employer demand.

2. There are very few exceptions to this approach, including small-scale job-search visas offered in a number of countries, yet even in these cases, the opportunity to remain at the end of the job search period is contingent on a qualifying job offer. Employers thus effectively set both the minimum and maximum potential for labour migration, although states can place conditions and ceilings on this inflow.

3. Employers also largely determine the category of labour migrant to be admitted, according to whether the candidate is to be hired under contract, as an independent contractor or service provider, or as an intra-company transfer remaining within the same multinational company. Finally, employers are actors and interested parties in influencing the development and reform of policy and legislation governing labour migration into Europe.

4. Most European countries have not placed numerical limits on the possibility for employers to recruit highly educated or highly skilled workers from outside Europe, subject to conditions on the contract and on the relative availability of local workers to fill the position. In many EU countries, and at the EU level, the emphasis has not been on reining in the number of highly educated and highly skilled workers, but rather on increasing their number. In fact, in sharp contrast to English-speaking non-EU OECD countries - the United States, Canada and Australia - the challenge has not been to pick from an excess of supply, but to increase the total number entering.

5. Increasing Europe's attractiveness for skilled and talented third-country nationals means ensuring that employers who struggle to fill positions are able to identify and hire the workers that they require at the right time.

6. Finally, there is competition among many OECD countries to attract investments through offering favourable residence conditions to investors and their families, although the effect of these programmes is still unclear.

7. This report examines three ways in which employers are protagonists in international labour migration, and what can be done to ensure that they are partners in increasing European attractiveness for internationally mobile talent. The first is intra-corporate transfers. The second is the access to foreign workers for small- and medium-sized enterprises. The third is the question of non-EU entrepreneurs and investors, and the extent to which they can be attracted to the EU single market

\section{Facilitating movement of Intra-Corporate Transfer (ICT) workers in multinational companies}

8. The contribution of transnational corporations (TNCs) to global GDP is significant. In 2012, the international production of TNCs continued to expand at a steady rate -foreign direct investment (FDI) stocks rose by $9 \%$ in 2012, to EUR 17.9 trillion (UNCTAD, 2013). Foreign affiliates of TNCs generated 
sales worth EUR 20.2 trillion (of which EUR 5.8 trillion were for exports), increasing by $7.4 \%$ from 2011 . They contributed value added worth EUR 5.1 trillion, up 5.5\%. While the growth of international production by the top 100 TNCs mostly from developed economies, stagnated in 2012, the 100 largest TNCs domiciled in developing and transition economies increased their foreign assets by $20 \%$, continuing the expansion of their international production networks.

9. Imports in services in the EU grew modestly by $0.5 \%$ in 2013 on the previous year but by $12.6 \%$ since the financial crisis of 2008. The balance in trade services for the EU was EUR 173.2 billion in 2013, a $13 \%$ rise from the previous year ${ }^{1}$. Germany, France, the UK and the Netherlands were among the major importing countries of such services trade. Most of these imports came from North America followed by Asian countries excluding the Arabian Gulf.

10. Transnational corporations also have transnational workforces, and moving these workers across borders is critical for big business with international operations. The globalisation of business and accompanying skills demand has made it desirable for multinational corporations to transfer employees temporarily to another branch or subsidiary. Intra-corporate transfer is not seen by these companies as the same as a local business recruiting a worker from abroad, as the worker is already employed by the same TNC. Governments often share this perception, leading to the creation of a status or category specifically for such employees: intra-corporate transfers. The United States has had a specific visa category for such workers, the L-1 visa, since 1970, focused on two sub-categories: managers and executives; and key workers with specialised knowledge specific to the functioning of the firm.

11. A provision for Intra-Corporate Transfers (ICTs) was introduced in 1995 to implement MODE 4 under GATS, to facilitate the movement of workers between TNCs having presence in multiple countries. In this regard the movement of workers, including those from emerging markets, as part of facilitated trade in a globalised economy has been continuously advanced among countries through several agreements international, regional and bilateral. For instance, the EU has entered into Free Trade Agreements (FTA) covering movement of natural persons with Chile, Korea, Mexico, South Africa and the CARIFORUM states $^{2}$ and these include provisions for ICTs. However, the current policy efforts are to go beyond the services sector and cover transfers that originate in a third country without any trade agreement.

12. The trade commitments made under the GATS, as well as bilateral agreements, are not intended to cover exhaustively the conditions of entry, stay and work. EU member states, as of 2010, had a plethora of arrangements with varying requirements to admit ICT workers, and in some cases, none. Perhaps more significantly, TCNs had to navigate each individual country's migration regulations for transfers working in more than country. Hence, a proposal was mooted to harmonize such criteria and provide an overarching framework (COM (2010) 378 final). This has now led to the adoption in 2014 (2014/66/EU) of the ICT Directive, after agreement on key provisions between the EC and Council and the Parliament. Member states have until November 2016 to transpose this directive into national legislation.

13. In the EU context, such facilitation has been identified as part of the efforts to support economic growth, innovation and maintaining competitiveness as well as fostering investment flows across the Union. The ICT directive is a further initiative in realising the intent of the

1 http://ec.europa.eu/eurostat/statistics-explained/index.php/International_trade_in_services

2 The Forum of the Caribbean Group of African, Caribbean and Pacific (ACP) States (CARIFORUM) comprises of: Antigua and Barbuda, The Bahamas, Barbados, Belize, Cuba, Dominica, Dominican Republic, Grenada, Guyana, Haiti, Jamaica, Suriname, Saint Lucia, St. Christopher and Nevis, St. Vincent and the Grenadines, Suriname, Trinidad and Tobago 
Treaty on the Functioning of the Union (TFEU) for efficiently managing migration flows and the fair treatment of third country nationals residing in member states.

\section{ICT inflows and trends}

14. Overall in the OECD, the United States continues to be the major destination for such transfer workers, although its levels have declined, while on the other hand the numbers continue to grow in Australia and Canada (Error! Reference source not found.1). In the EU, the United Kingdom remains by ar the largest ICTs recipient in absolute terms as well as on a per capita population basis. Intra-Corporate Transfers have increased by 15\% since 2007 (with a brief interruption in 2009), indicating sustained global business demand for specific skills (OECD 2014).

15. There is no disaggregated data on ICTs. The EU estimates that $16500-20000$ ICT workers, or about four $\%$ of all temporary migrant workers it receives, will come from third countries, requiring migration facilitation. The EU in its impact assessment estimated 17,500 ICT workers annually in the EU (including the UK and Ireland) or 15,500 without the UK and, based on the size of the member country and the number of ICTs in each country (EC 2010). These numbers are about twice what the EU received in 2012 as ICT inflows, if the U.K. is excluded (OECD 2014a).

16. In the EU context, however, these numbers do not include two important forms of mobility: posted workers within the EEA (those issued the E101, or now the A1 form) and transfers occurring under the EU free movement. Posted workers may cover both union nationals and TCNs and were estimated overall at 1.3 million workers in 2007 (EC 2011). Over half of EU free movement is estimated to be employment related though they may consist predominantly of EU workers and only a few of their TCN family members are likely transferees. Elsewhere, as in Australia, those meeting the ICT definition could well enter through several work visa categories or even as short-term business visitors, thus underestimating the real numbers. 
Figure 1. Inflows of Intra-corporate transfers in selected OECD countries, 2007-2012

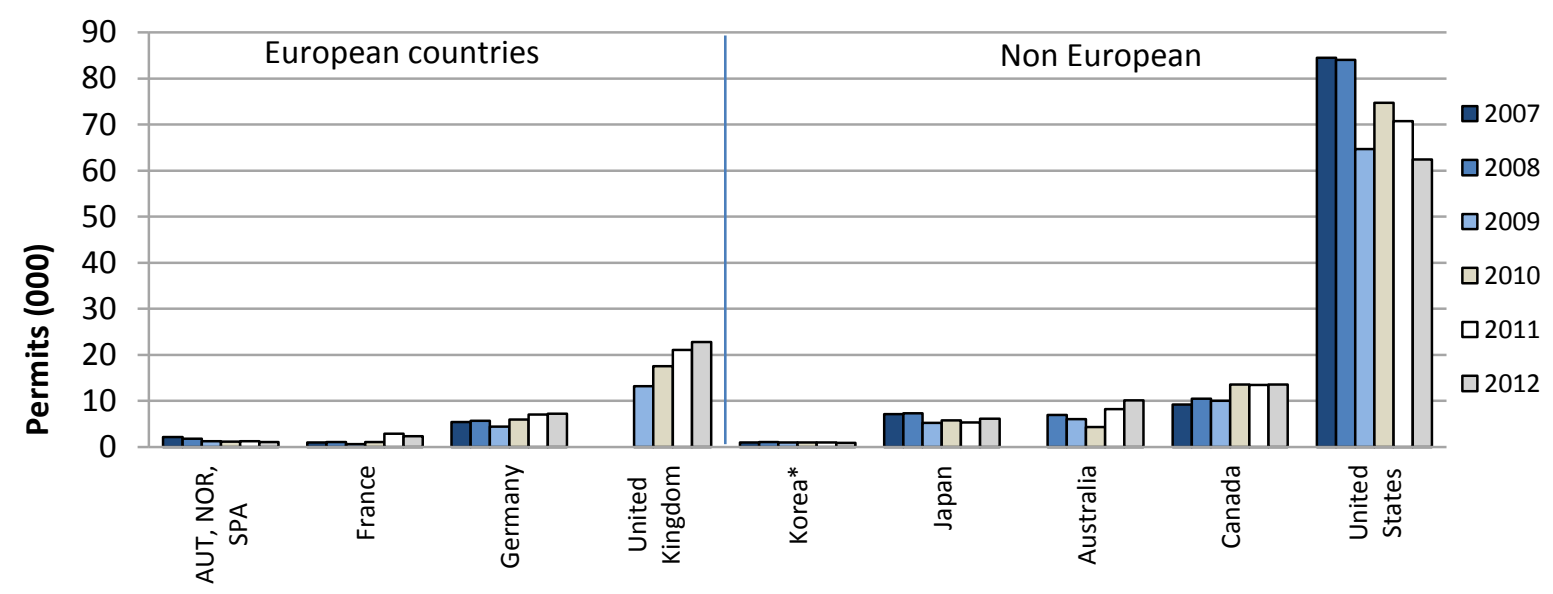

Note: Australia numbers are restricted to the Business (Long Stay) (subclass 457) visa where a person's visa application indicated they were travelling on an ICT arrangement. Some individuals who meet the ICT definition will come to Australia on other visas, including short-term business visitors.

Source: OECD secretariat analysis.

\section{ICT policy provision - the current state of play}

17. Prior to transposition of the 2014 directive, how do ICT provisions compare across the EU, especially among its OECD members, and also with non-EU countries in the OECD? There is some broad similarity in the overarching policy criteria used among OECD countries within their existing frameworks for admitting transferees from third countries. However, there is equally or more divergent criteria in how they admit transferees, enable their residence and work and the rights accorded to such third country transferees but also in the associated processes involved. Some countries have no specific schemes at all for ICTs.

18. A survey of member states for the commission's impact assessment in 2010 showed that at that time14 states had some sort of provision for ICTs in particular. There was general agreement on who constituted a ICT worker - generally identified as "key personnel" or "highly skilled personnel", but admission criteria and work permit durations varied widely across EU Member States. In Sweden, specialist or trainees working with an international group for less than 12 months are altogether exempted from work permits. Likewise, ICT trainees coming to Belgium for fewer than three months training do not require work permits. In France, for short term assignments under 3 months, it is not necessary to undergo a medical examination or to obtain a residence permit. ICTs in France ("salaries en mission") also include two types of employees: those who become employees of the French company; and those that remain employees of the foreign employer ("détachés"). In Slovakia and Romania, procedures for admission could be particularly long or difficult. Denmark, Netherlands, Austria and Czech Republic have required certificates attesting the level of education, qualification and previous training activities. While many member states tended to give equal treatment to family reunification, the conditions attached to such rights were again variable. The possibility for spouses to work rarely existed.

19. The wide differentiation between EU Member States and the lack of clear and/or specific schemes in some of them provided a rationale for developing a specific directive that would serve to bring 
alignment among member countries and ease the burden for international firms seeking to move workers to the EU.

\section{Defining who is a skilled Intra-corporate transferee}

21. Legislation must define what is meant by skill, and who is considered to be an intra-corporate transfer rather than, for example, a regular new hire or temporary visitor for training or installation.

22. One of the high-level principles is that the admission is reserved for high skilled workers typically specified as managers/executives, technical experts and trainees. They represent firm specific knowledge and technical skills or travel to receive exposure and training in the specific local environment. Denmark allows ICTs to work on a project or to carry out work that is "innovative, developmental or educational" in nature. In the case of Bulgaria, Australia and the USA, the scope also includes establishing a business or commercial activity in the new location. In many cases, the basic assumption is that the role is project-specific, not ongoing and requires firm specific skills and proprietary knowledge that cannot be obtained locally.

23. The evidence for substantiating that the role is indeed high skilled primarily rests on the declaration of the sponsoring firm on the role and responsibilities of the transferee. Few countries set objectively verifiable criteria for characteristics of the workers themselves. A bachelor level qualification is required in Belgium, Germany and Spain. Australia is the only country where language level is specified (English IELTS level 5) though even this can be exempt under certain conditions. ${ }^{3}$

24. In many cases, a wage threshold is set as a proxy for the skill and productivity levels involved. In Ireland, senior managers must earn a minimum annual remuneration of EUR 40000 and at least EUR 30000 in the case of trainees. Likewise, long-term staff applicants in the U.K. must be paid at least GBP 41000 and short-term staff and trainees GBP 24500 respectively. The Netherlands requires annually a gross salary of at least EUR 51 239, Belgium EUR 38665 and in France remuneration must be set at 1.5 times the minimum gross monthly wage ("Salaire minimum de croissance", or SMIC). Australia determines market rate either by benchmarking to an industrial award, common law or other evidence such as industry surveys ${ }^{4}$. In this regard, several European countries also refer to the collective bargaining agreements or in the absence of which to obtain a declaration from the employer that it meets such standards. In Denmark, salary as well as employment conditions must correspond to Danish standards for skilled workers and Irish ICT permit holders are to be employed, salaried and paid under a domestic or national employment contract.

25. Maintaining wage parity with comparable local occupations is also a safeguard against lower wages of sending countries that can undermine fair competition by allowing companies to circumvent regular labour migration legislation and recruit at below local market wages.

\section{Not all firms are eligible}

26. The privilege to use intra-corporate transfer is not open to all firms. Criteria applicable to the firms themselves include size, business turnover and even the location of the directing authority for the transferee. In the Netherlands, the company group must have minimum revenue of EUR 50 million and a

\footnotetext{
3 Criteria include a minimum AUD 85090 annual salary, be on the high skill occupation list and have 5 years continuous education in high school and university.

4 At the minimum, it is linked to the Temporary Skilled Migration Income Threshold (TSMIT), a threshold which ensures that overseas workers will have enough money to be self-reliant while in Australia. A standard business sponsor is not required to demonstrate payment of market salary if the proposed annual earnings of nominee is above exemption rate set at AUD 180000.
} 
worldwide-acting company, according to the German foreigners' office, is a company whose foreign part of the business (holding company or subsidiary) holds a capital share of at least 50\%. In Denmark, the company should employ a minimum of 10 employees where it has to obtain corporate approval status. France does not mind whether the employment contract is with the foreign or the local entity. In Canada, the location of the authority to direct the employee on a daily basis must lie with the Canadian entity. New Zealand applies similar rules.

27. In most situations, however, there is a requirement to establish the relationship between the entity (a parent, subsidiary, branch or affiliate of the multi-national company) and the transfer worker. For many countries, a period of 12 months' prior employment with the company in the last three years is a standard. The U.K. provides for a varying period of prior full-time employment duration with the entity - no minimum time for those wanting to train, three months for graduates and for other transferees this is either under or over 12 months depending on whether the posting is for less or more than a year. In 2013, Spain reduced this requirement of attachment to the firm from nine months to three as part of a wider bid to reform migration rules for improving its economic competitiveness.

\section{Family reunification}

28. In almost all countries immediate families, both spouses and children, can join the transferee, subject to evidence of funds for maintenance. However, whether this happens simultaneous to the transferee arriving at their job or subsequently, the rules vary across countries. As regards access to the labour market and work rights, most countries do not grant work rights to family members. Denmark and the U.K. grant work rights. The United States allows spouses of ICTs to work. In Ireland, Australia, Japan and Korea, spouses do not have automatic rights to work and family members have to go through a regular process to acquire a work permit.

\section{Additional safeguards}

29. Countries have also attempted to ensure that the ICT channel does not function at the cost of opportunities for domestic workers. Since they are, in principle, temporary roles, most countries do not have a labour market test for ICTs. One exception outside Europe is Australia, where ICTs are subject to the temporary skilled workers (457 visa) program, which includes the recently-imposed labour market assessment, although this is not a vacancy period requirement. Recently the Swedish Migration Board has updated their recruitment advertisement requirements to include applications for Intra-Company Transferees. Accordingly, ICT applications must now also provide proof of where and when the position was advertised, along with the advertisement ID or reference number ${ }^{5}$. In Ireland, an ICT Employment Permit is not available for positions which are listed on the list of Ineligible Categories of Employment for Employment Permits.

30. Some countries attempt to set limits on the share of employees in a firm who are ICTs. For instance, the number of foreign employees with a residence permit under the Danish Corporate scheme (for getting corporate approval status) should not be "disproportionate" to the total number of employees though no number is specified. The United States increased petitioner fees to $\$ 2250$ for certain L-1A and L-1B applications where employers have 50 or more employees in the United States and more than 50\% of their employees in $\mathrm{H}-1 \mathrm{~B}, \mathrm{~L}-1 \mathrm{~A}$ or L-1B non-immigrant status petitions. ${ }^{7}$ The aim is to disincentivise firms that increase their relative proportion of overseas workers even if these are temporary workers. Germany ensures neutrality of impact on the local labour market by insisting that the exchange of

\footnotetext{
5 https://www.aires.com/News/IndustryNews/SwedenRegistrationsRequiredByJuly1.html

6 http://www.djei.ie/labour/workpermits/intracompanytransferep.htm

$7 \quad$ Public Law 111-230, 2010.
} 
personnel between the local and the overseas entities are roughly the same in terms of the number of employees involved - "10 in / 10 out". In Ireland, ICT workers could not be more than 5\% of the firm's workforce.

31. At this time, however, most countries have not imposed numerical limits on the number of ICT workers and this scheme, wherever explicitly established, generally remains uncapped. Romania has had caps in place for ICT workers and has indicated setting aside 900 places for ICT workers of the total 5500 work permits quota announced for 2015.

32. In order to maintaining this temporariness, the maximum duration of such postings is usually limited. In North America, the maximum duration is higher than in Europe, with a maximum duration of seven years for certain ICT workers (See 2).

Figure 2. Maximum duration of ICT permits (years)

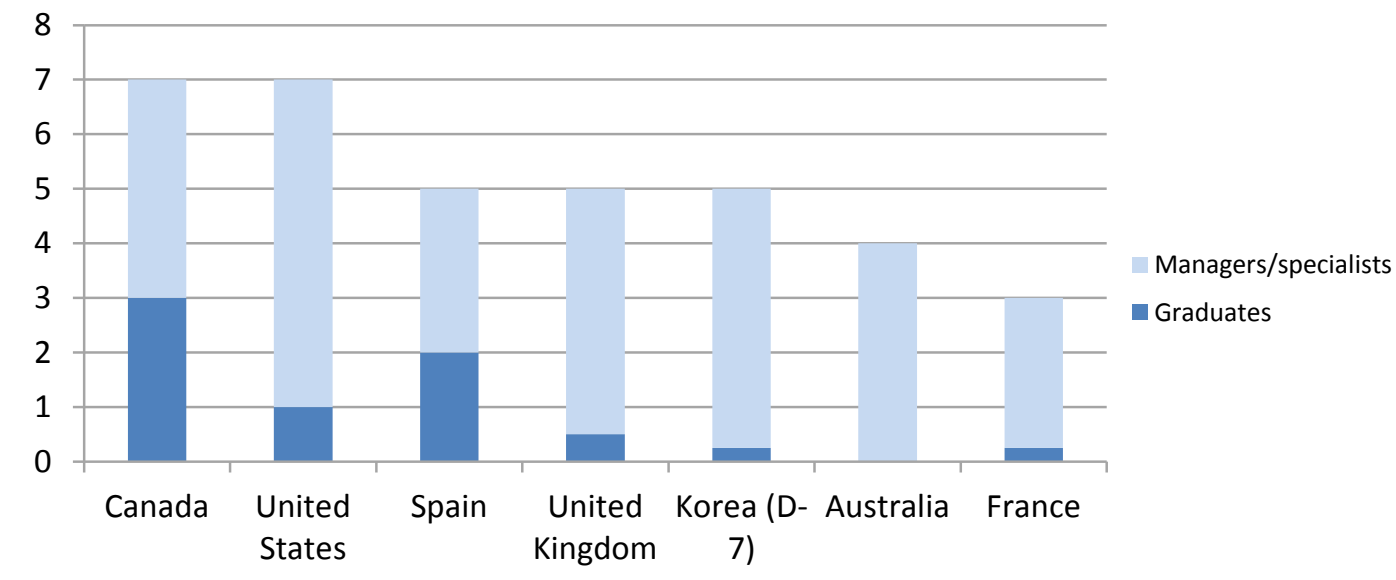

Note: Korea (D7/8) inflows based on estimations. In France the maximum can be extended to 6 years if employee transfers to national payroll. In Canada and the U.S the maximum is 5 years for executives and 7 years for specialists.

33. In practice, however, some countries do allow repeated renewals. For instance in Austria, ICT workers from third countries are subsumed under the regulations for so-called "rotational workers". Both residence permits and hiring permissions are usually issued for a period of 12 months, unless the employer specifically asks for a shorter duration. Residence permits for rotational workers may in theory be renewed for an indefinite number of times (provided that the applicant continues to fulfil the granting requirements). While this should involve a new labour market test, the Austrian employment service (AMS) usually considers the test as passed in renewal procedures. Anecdotal evidence suggests that indeed it is not uncommon for rotational workers to stay in Austria for several years (OECD 2014b). Similarly, in Belgium, the Work Permit B can be renewed almost annually. In France, an ICT can receive a renewable three-year residence permit.

34. Many countries do not allow intra-corporate transfers to transition to permanent residence, accumulate residence for the purposes of naturalisation, or even to change status to regular employment without leaving the country. The United States is noteworthy, as it does allow ICTs to apply for permanent residence. In the U.K. there is the possibility to hold a second job (20 hours)during the ICT period, if it is outside the sector, although this requires sponsorship under the standard work permit category unless the job is on the skill shortage list. While the U.K. has a cooling-off period of 12 months before being eligible to switch to another ICT permit, an ICT worker might be allowed to stay longer if they meet a high income threshold (over GBP 153500 per year). In Ireland, current holders of Irish ICT Provider Employment Permits can now apply for other types of Employment Permit subject to the normal programme criteria. 
Likewise in Australia, an ICT worker can change jobs within the same temporary labour programme, though the new employer must go through the sponsorship process as if for a new hire.

\section{Processes to expedite visa issuance}

35. A number of countries do facilitate faster processing as long as companies meet requirements. The U.K. provides for a premium service that helps fast track processing at an additional cost. Under the 2013 changes in Spain, undertakings or group of undertakings that meet certain requirements may apply for collective authorization or "batch processing" of ICT applications (Law 14/2013, Art 74). Danish companies that meet the requirements for "corporate approval" can expect applications for ICT employees to be processed faster. Similar provisions apply in the Netherlands but in both countries these are optional for firms to apply for such sponsor status.

36. In the US, a blanket petitioner ${ }^{8}$ or individual applicant can avail a Premium Processing Service that guarantees processing in 15 calendar days to those users or will refund the special fee. Australia has streamlined processing arrangements to help ICT workers and these include transfers between Asia Pacific Economic Co-operation (APEC) member economies.

\section{Salient features of the ICT Directive 2014/66/EU}

37. The Directive aims to harmonise existing arrangements for ICTs movements among member countries with the exception of the United Kingdom, Ireland and Denmark that are not bound by this directive.

38. With regard to admission, the ICT directive provides precise definitions on what constitutes a group of undertakings (Art.3.L - e.g. where an undertaking holds a majority of its subscribed capital, controls a majority of the votes attached to its issued share capital) and the maximum duration (Art.12.1) for ensuring temporariness (e.g. maximum duration of three and one year for managers, specialists and trainees respectively). Likewise, standards are specified (Art.3.e) for skills and qualifications of the three generic categories of manager, specialists and trainee. The skill levels and experience for these roles will be substantiated by the employer through evidence that the transferee has the required management or professional qualifications and trainees have a university qualification at the minimum. Member states are asked to use the European Qualifications Framework to assess the equivalence of transferees' qualifications ${ }^{9}$.

39. Some of the key principles are first described followed by what may be termed as limits and then discussion around the margins available for member states while transposing these directions into national laws.

\section{Procedural simplification}

40. Firstly, the directive paves the way for a "single application procedure" (Art 11.5) which combines both residence and work authorisation for a third country national in a member state. ICT and

$8 \quad$ Certain U.S. firms may establish the required intra-company relationship in advance of filing individual L1 petitions by filing a "blanket petition". Typically, firms with commercial activity for over a year and meeting additional criteria such as having filed 10 L-1 applications in the last year, qualify for this status, which provides the employer with the flexibility to transfer eligible employees to the United States quickly and with short notice without having to file an individual petition with USCIS.

9 Directive 2005/36/EC of the European Parliament and the Council of 7 September 2005 on the recognition of professional qualifications (OJ L 255, 30.9.2005, p. 22) 
posted workers were excluded from the 2011 Single Permit directive (2011/98/EC) as they were not considered part of the labour market where they were posted. The directive also provides for making easily accessible all information at the outset to the applicants on the documentation required for single entry procedure, the rights and obligations and procedural safeguards of the ICT and their family members. Simplified processes (Art 11.6) are suggested for recognised employers or sponsors (e.g. exemption from some of the evidentiary requirement) as well as fast-track procedures (Art 11.7.b) such as final approvals done in shorter time than the maximum of 90 days set for general cases.

\section{Equal treatment with union nationals}

40. Making remuneration on par with nationals of member states occupying comparable positions serves to ensure fair competition but also to protect the ICT worker from exploitation. While (Art. 5.4.b, the directive does not make any reference to wage levels., on all "other aspects of terms and conditions of employment", transferees will enjoy at least the same rights (Art 18.1) as posted workers ${ }^{10}$, therefore ensuring that the undertakings in the sending countries do not receive more favourable conditions than firms in member states. For this purpose, they will refer to collective agreements in the relevant geographical area applicable to similar undertakings or professions or industry. Further, rights are also accorded on the same lines as for nationals with regard to social security particularly sickness, invalidity and old-age benefits.

41. In the absence of collective agreements, the directive does not specify the benchmark for prevailing working conditions (other than remuneration). Further, member states may not grant rights to family members on social security provisions, when the duration of stay is less than 9 months and can make exemptions to instead apply the country of origin laws if so deemed by national law or bilateral agreements ${ }^{11}$. The directive does not attempt to harmonise social security legislation of member states other than limiting the principle of equal treatment in the field of social security to ICT workers. Nor is it clear why linking parity with conditions for posted workers when the Posted Workers Directive in itself is under revision.

\section{Short and long-term mobility}

42. A significant third feature aims to reduce administrative burdens associated with working in multiple member states. To this effect, the directive now specifically provides for intra-EU mobility short- and long-term moves - to other member states from the original state which issued the ICT permit for admission. The short-term mobility (Art.16A) covers stays of up to 90 days (in a 180 day period) and the long-term (Art 16B), durations of over 90 days without ICTs having to apply for visas. The latter has more conditions attached to it than for the shorter stays. Short-term mobility is the same as that one provided by the Common Schengen visa code where formalities are reduced to a notification (Art.21). This is an application of the principle of mutual recognition. The long-term mobility gives a choice to the second state: either recognise admission of first state or insist on a new admission procedure.

43. To prevent the misuse of this provision, for instance by repeatedly extending durations, notifications for short term and application for long term to the second member state may not be made at the same time (Art 22.2.e). The second member state will require a minimum of 20 days' notice for a longstay before the expiry of the short-stay. If the intent to work in the second state is known at the time of original permit application, then the second state needs to be informed at the same time along with details of contract and assignment letter and whether it fulfils conditions for a regulated profession if that is the

\footnotetext{
10 Directive 96/71/EC of the European Parliament and of the Council of 16 December 1996 concerning the posting of workers in the framework of the provision of services

11

http://eulawanalysis.blogspot.se/2014/11/the-new-directive-on-intra-corporate.html
} 
case. The mobility provisions are thus subject to safeguards and sanctions (Art.23) such as detailed evidence to support movement for the same work in the second member state.

\section{Rights to family reunification}

44. Finally, an important right (Art 19.4) is accorded to family members, to accompany the transferee at the time of arrival or when moving on long-term mobility. This borrows on Directive 2003/86/EC and does not insist on a minimum period of residence or prospect of gaining permanent residence for the ICT (Art 19.2). Furthermore, family members are accorded rights to work or self-employment for as long as transferee holds valid permit (Art 19.6) in both the first and second member states. This is a significant right not previously provided in many EU countries covered by the directive. Family members are now accorded equal mobility and carry-over of such rights when moving to another member state along with the ICT worker provided it involves long-term mobility. The right to family reunification, however, is limited to core family members such as spouse or minor children only.

\section{Discussion}

45. The provisions relating to wage parity and social security with nationals, rights to family reunification and work rights of family members and intra-EU mobility for workers and families are major steps in enabling international enterprises to moving key resources within their companies at short notice for business purposes. Some of the salient features will go to considerable length in alleviating the concerns of such TNCs while also ensuring that transferee workers and their families enjoy key rights and parity with domestic workers on core employment aspects like wages.

46. Harmonising approaches pose opportunities and challenges especially between rigidity and flexibility for implementing member states. The directive as in Art 2 (3) makes it imperative that member states do not maintain parallel schemes for ICT workers. As long as applicants fall within the scope of ICT workers, the directive is the only instrument. However, even if an applicant fits the criteria, member states do have, under the Volumes of Admission (Art.6), the right to not admit or reject.

47. The procedural criteria specified in the directive could be rather rigid and the required documentation extensive; this may complicate the currently rather liberal national admission procedures; but the possibility to provide for simplified procedures in national law (that has to be in conformity with the basic rules of the directive) remains open as in Art.11.6-8; this raises the question whether the directive in the end will produce the liberalisation intended by the Commission or rather the opposite. For instance, Art 5 provides for a range of admission criteria such as evidence of attachment to firm, a contract and letter from employer outlining details of role, qualifications etc. This could be a strain for companies to comply with especially where existing provision are rather straightforward. For example Spain provides for a single permit and automatic authorisation if the concerned agency does not respond in a maximum of 20 days. It will be interesting to see how many member states use the "more favourable position" as in Art. 4 if they cannot ease entry requirements in admission conditions.

48. States have substantial margins around how they set limits. For instance, states can impose the temporary nature of the role by imposing a "cooling off" period between two concurrent ICT permits. After the maximum periods for stay have been completed, ICTs are required to exit the member state before applying for another ICT visa/permit. The cooling off period between two such applications is to be determined by member states, and can be set at zero though Art 12.2 states that member states "may require a period of up to six months to elapse between the end of the maximum duration of a transfer and another ICT application" in the same member state. ICTs can always apply for another residence permit in line with union or national laws(Art 12.1). However, if ICT workers meet the threshold for high skilled workers, what makes them subject to rigid conditions on status change from one ICT permit to another? 
There are examples as in the UK case where exemptions can apply. It is not clear if it is about ensuring temporariness of the role specifically or the temporariness of the worker and the latter's intent to remain in the member state. It is possible that some member states may have been concerned with triggering longterm residence or even citizenship at the 4-5 year point (Lazarowicz, 2013).

49. A number of obstacles can persist even after transposition. One such question is the assessment of qualifications which can be required for regulated professions. Equivalence will depend upon the extent to which the European qualifications framework can apply to a growing range of third country qualifications. At the same time the directive admits restrictions which are not currently used, for instance through the prerogative of individual countries to impose numerical limitations like the volumes of admission although few seem to apply these currently. Romania is the one country that has so far used quotas. The effects of quotas, if applied, can be two-fold - to reduce ICT migration flows directly or indirectly impact on overall labour migration as it reduces scope for other labour migrants. The quotas become more complex when secondary transfers in intra-EU mobility are considered especially mobility from a non-Schengen state (e.g. U.K) to a Schengen state. If quotas were to be applied in this case, it is not clear how this would be treated in the case of an ICT worker moving from the UK as it is not a third country as per the directive.

50. Details left to national discretion in the Directive are often subject to various interpretations. One example is the benchmarking to collective agreements for reference to wages. All types of occupations may not necessarily be covered by collective agreements. Where agreements are not available, standard labour market information relating to wages may not suffice especially in large member states with considerable regional variations.

51. Finally, there are new patterns of short-term travel where third-country employees on crosscountry projects must work at sites in different member countries for a few or several days constantly over a period of time. Such short-term ICT workers might also be classified as a business visitor coming for a few months. In the absence of visa provisions to cover such short notice intermittent travel, it may be necessary to expand the definition of ICT workers. At the same time, if the processing regime for skilled temporary workers is very efficient, dedicated ICT arrangements may not really be that attractive for companies.

\section{Recommendations}

- With regard to equal treatment, while wage parity with nationals is now ensured, firms retain the option to impose prevailing employment standards in sending countries that have lesser conditions than in the member state, as they may with posted workers. While countries may choose to address this under "more favourable provisions", consider whether equal treatment should be extended to other core aspects of employment, besides wages, such as hours of work, holidays, minimum wages, health and safety and pregnancy.

- The principle of mutual recognition is applied in the case of short-term mobility and to consider if this principle can be applied to long-term mobility too as the scrutiny of the first state to admit already meets with a high test. For both certainty to companies and overall attractiveness, a general decision would be better than a case by case approach.

- Recognise evolving business needs and emerging short-travel patterns of some ICT workers and consider less stringent conditions of admission for such workers when the entity has already met standards for a recognised employer or sponsor set by national legislation or administrative practices of the member states, as the Directive allows. 


\section{Improving the ability of small- and medium-sized enterprises to access foreign workers}

52. Employers are major beneficiaries of labour migration and as the principal source of demand for labour, they are a key actor in the migration and labour supply chain. Rodriguez (2004) refers to them as labour market gate-keepers on a continuum between passive hirer to central organiser.

53. Yet Europe's 23 million small and medium enterprises (SMEs) accounted for over 98\% of businesses, provided two thirds of the total private employment and around $80 \%$ of new jobs created between 2005 and 2010 (EC 2011c). The same study stated that SMEs are seen as primarily responsible for wealth generation and economic growth, besides fostering innovation and R\&D and that many of these firms are very small: nine out of ten SMEs are actually micro enterprises with less than 10 employees.

54. In the context of trade, that whilst still a small share of total EU enterprises (exporters and nonexporters), more than 750,000 EU SMEs are engaged in extra-EU exporting activities (Cernat et al, 2014) and account for over EUR 500 billion merchandised exports (over a third of the EU total).

55. These firms face challenges for recruiting from outside of Europe when facing a need for skilled workers. Small firms may be less likely to risk hiring unknown employees, especially when the sponsorship requirements are complex and costs are high. Small firms, especially in countries with limited or no language basin abroad, may face difficulty in accommodating workers who speak their language poorly.

56. The question arises as to how SME employers are engaged in this process through existing EU policies and mechanisms for attracting migrant workers from outside the EU. More specifically how attractive are these provisions for Small and Medium sized enterprises ${ }^{12}$ in the EU to access such third country workers compared to privileges that larger enterprises may enjoy as in the case of TNCs discussed in the previous section on ICTs.

\section{An overview of the SME workforce}

57. There is no systematic information on what issues SMEs may face specifically with regard to recruitment of third country nationals. Nor for that matter specific evidence on the different costs that SMEs may incur in such international recruitment compared to larger firms.

58. However, a comparison of the foreign-born among the workforce is a useful starting point to see whether SMEs make use of foreign-born workforce. An analysis of the distribution of native- and foreignborn workers (Table 1) in the workforce shows a more or less equal share of both groups across most firms with 11 to 19 persons. For firms with over 20 persons and above, native born are relatively more present in the workplace. However, there is a marked difference when looking at firms with 10 persons or less, where the share of foreign-born is higher-compared to native-born. While foreign-born elsewhere in the EU count for 29\%, interestingly non-EU foreign-born make up 33\%. This suggests that SMEs do have a higher proportion of third country nationals and are capable of employing immigrant workers. Further, many selfemployed or entrepreneurs, are also migrants, and likely overlap with migrant SMEs. Such migrants were estimated at $12.6 \%$ of the working age population, compared to $12 \%$ among natives (OECD 2011a).

12 The European Commission defines SMEs as employing fewer than 250 persons and an annual turnover not exceeding $€ 50$ million. 
Table 1. Workers distribution across firms, by origin, 2012

\begin{tabular}{|l|r|r|r|}
\hline Number of persons working at the local unit & $\begin{array}{c}\text { native- } \\
\text { born }\end{array}$ & $\begin{array}{r}\text { foreign- } \\
\text { born (EU) }\end{array}$ & $\begin{array}{r}\text { foreign- } \\
\text { born (non- } \\
\text { EU) }\end{array}$ \\
\hline 10 persons or less & 24 & 29 & 33 \\
\hline 11 or more & 5 & 4 & 5 \\
\hline 11 to 19 persons & 11 & 10 & 10 \\
\hline 20 to 49 persons & 43 & 15 & 14 \\
\hline 50 persons or more & 100 & 41 & 37 \\
\hline Total & & 100 & 100 \\
\hline
\end{tabular}

Source: European Labour Force Surveys (Eurostat). Note: For workers aged 15-64. The data excludes Germany because no information on the country of birth is available.

59. Similarly when looking at where foreign-born tend to work mostly especially for firms with less than 10 employees, such workers are found concentrated among a number of diverse industries such as Agriculture, Manufacturing, Construction, Wholesale and Retail, Accommodation, Health and Social Services, Professional, Administration and Household activities. Some of these sectors such as construction are generally associated with higher prevalence of SMEs (see tables A.1 and A.2 in the Annex). In almost all industries, there are more non-EU born foreign workers compared to EU born foreign workers. This analysis though does not distinguish between foreign workers and immigrants who have arrived through other channels. Nonetheless, these figures reveal the high shares of non-native workers in SMEs. The share of foreign-born employed in SMEs is especially high in some countries such as Germany, France and Italy.

60. The picture of foreign-born employment is important in light of projections of future labour and skill needs expected to confront SMEs. According to an analysis conducted for the DG Enterprise and Industry (Buschfeld et al. 2011), focusing on micro- and craft enterprises skill needs expected to increase by 2020 include: customer and market orientation, working in cooperative and collaborative international work structures, and management skills. Increasing orientation toward foreign markets was also driving skill needs in all sectors resulting in companies needing language skills for analysing foreign markets and communicating with foreign partners. While the study points to the type of skill needs that will arise in the medium term, there is no quantification of the skills required at different levels.

\section{What may hinder SMEs ability to recruit foreign workers?}

61. SMEs already employ foreign-born workers, and their skill needs are expected to increase in the near term. In general, large companies have less difficulty than smaller firms in recruiting workers from abroad. Ensuring SMEs equal access to channels of recruitment of non-EU workers from abroad then, is a particular challenge. Unlike larger organisations, SMEs may not have dedicated human resources staff and may not be engaged in longer term HR planning or comprehensive recruitment activities. Larger companies are able to develop competences in administrative procedures, benefit from economies of scale in recruiting, are more likely to be known internationally. HR may be seen as peripheral to core business activities and senior management may see HR as one small area competing with multiple strategic priorities (Allies 2012). Larger employers also have the capacity to access intermediaries and private HR firms to undertake checks on documents and qualifications which SMEs may not be able to manage or afford. Larger employers may also have the resources to participate in international job fairs and international recruitment missions to source workers resident in other countries. Further, larger companies 
with multinational presence can benefit from specific programmes such as intra-corporate transfers to bring staff from abroad.

62. Two issues confronting employers in general which may have a disproportionate effect on SME employers are restrictive immigration policy settings and specific administrative costs associated with international recruitment. The first was cited in an international survey of entrepreneurs in 2013, although these do not specifically reflect small and medium enterprises.

\section{Figure 3. Immigration laws prevent your company from employing foreign labour", approval rates of employers from OECD countries, 2013}

\footnotetext{
Note: The graph shows the rating results to the question: "Immigration laws prevent your company from employing foreign labour", 0 - does not apply, 10 - does apply (the original question and rating scale have been reversed for clarity).

Source: IMD World Competitiveness Yearbook 2013.
}

63. How employers perceive their national laws as facilitating or restricting immigration is a reflection of this attractiveness for foreign firms and workers alike. Looking at Figure 3, countries like the United States appear at the restrictive end of the scale and Sweden at the other end. Paradoxically, the United States, despite or perhaps because of this perception, faces over-subscription for many work categories, while Sweden's favourable regime does not correspond to large inflows. Admission policy is only one part of a country's attractiveness for labour migrants. For example, a survey of German employers, conducted in 2011 (OECD, 2013), showed employers were unfamiliar with actual German policy settings, which were more favourable than employers believed. Changing perception about the laws - and the need to heighten awareness of the actual law and its conditions - are a necessary part of the efforts that countries must undertake when they face competition in global skilled recruitment.

64. While small firms appear less familiar with legislation, those which have an international orientation of firms unsurprisingly have less difficulty recruiting. A study by Constant and Rinne (2013) synthesises experience of SMEs across Germany and draws on a 2010 survey of German firms (in Bahrke et al 2011). For instance in the German federal state of Baden-Wurttemberg, the study found that internationally oriented and exporting firms tend to rate all international recruitment channels highly compared to non-exporting firms. Yet, firms with less than 50 employees perceived all channels as rather unsuccessful with the exception of personal contacts and public employment services. In addition to the barrier represented by a disadvantage of scale - it is likely that employers are also less aware of successful strategies and sources to recruit workers - both in general and from overseas. The same study found, almost nine in ten German SMEs generally have problems in finding employees who appropriately match 
their vacancy, although German firms may be pickier than firms in other OECD countries (OECD, 2013; OECD 2014b).

65. All work permit and visa requirements for recruiting non-EU workers add costs - in terms of time and money - to the recruitment process. These added costs play a role in ensuring that employers favour locally available workers over new recruits from abroad. Yet, in cases where positions cannot be filled locally within a reasonable time frame, lengthy, unpredictable and rigid procedures can discourage employers in recruiting from abroad.

66. Applying a trade facilitation perspective to entry procedures for persons, specifically visas and work permits, a Swedish study (National Trade Board 2015) finds that entry procedures for persons may have substantial effects on companies in the form of increased costs, delayed projects or deliveries, inefficient operations, and sometimes lost contracts or opportunities. This study also argues that some types of trade are more sensitive to costly or unpredictable entry procedures for persons than others such as trade in services or trade by small companies and new market entrants, as the latter have relatively less capacity to handle complex procedures than large or incumbent firms.

67. In a regular survey (albeit one conducted by a pro-immigration lobby), held in 2014, eighty-six percent of U.S. employers responded that timely, predictable, and flexible visa availability are critical to at least some extent, up from 70 percent in $2013^{13}$. In the case of firms with fewer than a thousand full time employees, this increased sharply to $66 \%$ in 2014 from $46 \%$ in the previous year. While a comparable survey for firms with different employee sizes are not available for Europe, it does highlight the importance, that the time and cost involved in immigration fees and processes can be a considerable burden for firms (p.210, OECD 2014a).

68. Once new workers arrive in the country, employers may still face issues with their early settlement in the work place and integration in the wider community. German SMEs stated that they face problems in integrating workers from abroad, especially low skilled workers (Constant and Rinne, 2013). There are a number of problems in integration for new workers in SMEs, where employee numbers are small and new employees are expected to fit into an existing team. Language skills - beyond vocationspecific language training - and work place communication skills may make a difference. Small firms generally do not have a community of expatriates and their families to which they can provide services, so may have to rely on networks of businesses, employer associations, chambers of commerce and cooperation with local authorities. One example is the efforts by SMEs in small Norwegian towns to bolster their support network for skilled foreign workers by providing reception services for spouses and creating an international school for children (OECD, 2014b).

\section{Existing policy instruments and mechanisms for employers and SMEs}

69. Current EU instruments in the area of labour migration focus on the supply side: that is, on migrants, their characteristics and their rights and obligations. Beyond the characteristics of occupations, there is very little discussion of the demand side, and no provisions to directly engage employers.

70. A quick review of the EU instruments to date show that some may favour larger firms. The latest ICT directive discussed earlier aimed at facilitating international trade in services is one such example. This Act provides for simplified procedures to recognised undertakings and exempts the applicant from presenting some of the mandatory evidence otherwise required. The directive also enables such employers a fast-track admission procedure for both ICT permits and visas.

13

Council for Global Immigration Employer Immigration Metrics: 2014 Survey Results 
71. The Blue Card directive (2009/50/EC) provides for easier admission and fair treatment of high skilled migrants. However, SMEs may not entirely benefit from the introduction of the Blue Card. For instance, in the case of Germany it has been reported that their SMES are more likely to have stronger demand for workers with low and intermediate skills that are outside the scope of the blue card criteria (Constant and Rinne 2013). The 2011 OECD/DIHK employer survey showed that demand for low and medium skills was predominant in small and medium sized firms (even though over $40 \%$ of medium sized firms also reported demand for high skills) (OECD 2013). This means that workers cannot initiate the process unless a vacancy is established. And in this regard, the reach of SMEs is rather limited and therefore they may tend to default to a passive approach - respond only when they receive applications from third country nationals.

72. There are other minor indirect concessions for employers. The Single Permit directive (2011/98/EU) rationalises the number of steps required and agencies involved in applying for a residence and work permit. It provides a margin for member states to allow either workers or employers or both to apply for the single permit. This could possibly make it easier for employers to have control over the process and be certain when their overseas workers can arrive and start work. For SMEs in industries that are cyclical or seasonal in nature and require mostly low skilled workers for short temporary spells, the Seasonal Workers Directive (2014/36/EU) provides mainly for streamlined admission and protection of rights of such vulnerable workers. However, the directive also provides for one extension of workers' stay, where seasonal workers extend their contract with the same employer or even with a different employer, provided that the maximum period is not exceeded. Continuing with the same employer can be advantageous to both the worker and the employer even if the latter is not specifically a SME.

73. Few OECD countries currently have labour migration instruments specifically targeting or favouring SMEs. One example is Korea, where the non-professional temporary foreign worker programme is specifically designed to meet labour demand in small and medium enterprises, and cannot be used by large employers. The United States does not favour SMEs but does penalise employers who are reliant on large numbers of H-1B temporary professional workers. On top of the base filing fees, U.S. employers having more than 50 employees where more than half of those employees are in H-1B or L-1 nonimmigrant status, are required to pay an additional US\$ 2000 per petition since 2011.

\section{Employer engagement tools and mechanisms}

74. The directives such as the Single Permit Directive are, as discussed, mainly aimed at third country nationals coming for the purpose of employment, and may potentially benefit SMEs through their influence on the ability to recruit workers and the costs, delays and conditions associated. Likewise at the national level, there are few instances of SME-centric labour migration policies. Nevertheless a range of mechanisms and practices do abound in EU countries which involve employers in various ways to ensure that their needs are taken into account in labour migration regulations. Public consultation (OECD 2014a) is one such engagement, widely used when identifying skill shortages. Two examples are France's shortage lists, finalised following consultations with employers, and the U.K. Migration Advisory Committee's evidence-collection consultation for the Shortage Occupation List used for exemptions. Other examples of employer consultation include the caps-setting process in Italy, Slovenia's tri-partite body consultation and the stakeholder consultation process introduced by Greece in 2014 for determining its Volumes of Admission. All these examples allow employer demand to be taken into account while balancing safeguards for local workers and wage conditions.

75. Formal consultations involving employers can also take different forms. They could be sectoral (the short-lived 2005 German Green Card scheme arose as a result of discussions with the ICT sector), strategic or systems change (as in Canada, which holds industry consultations on long-term labour market needs or change over to the new Express Entry selection), social dialogue (Spanish 2004 consultations), or 
consultative commissions (Sweden's 2000 Commission on migration). There are also examples of policy co-production, as in New Zealand's seasonal worker policy, designed together with employers and social partners (OECD 2014a).

\section{Specific services for employers}

76. Employers must identify a pool of workers from which to choose. This could be as simple as announcing a vacancy and awaiting candidates, but this might not yield the right candidates, let alone the best candidates. Whether this includes third country nationals abroad depends on the extent to which they are a distant and unfamiliar resource. Job fairs are one way to mediate such information provision and matching between migrant workers and employers.

77. Many OECD countries have used such fairs to meet regional or sector labour shortages. The European EURES network also regularly holds job fairs where employers have the opportunity to meet a number of applicants from other EU countries. At the job fairs, employers have the opportunity to provide information about their company as well as possibility to conduct job interviews.

78. Within the EEA, such fairs are not unusual although they usually target EEA nationals and build on the existing framework for supporting mobility. In Germany, the foreign branch of the Employment Agency, the ZAV, originally set up to place unemployed Germans abroad, has expanded its incoming services - that is, for persons abroad seeking employment in Germany - organising recruitment fairs for German employers in co-operation with the local employment agencies in countries such as Spain. Norway's public employment service also draws on the EURES network to arrange job fairs for specific occupations in other EEA countries such as Portugal.

79. Settlement countries ${ }^{14}$ with migration targets have held government-organised job fairs abroad for several years, especially for the medium to high skilled, to ensure that economic migration is closely matched to job opportunities. The job fairs are also occasions to answer questions about migration regulations.

\section{Job matching}

80. Most job fairs are limited in scope and necessarily target specific sector or occupation needs. On the other hand, all EU member country governments already provide matching services, creating virtual marketplaces taking advantage of digital online technologies through web portals and databases where employers and migrants can lodge vacancies and post their CVs to enable faster matching.

81. A region wide arrangement involving the PES is the European Job Mobility Portal that provides job vacancies from 31 European countries, résumés from interested candidates and guidance on recruiting migrants. The Portal is supported by public employment services and EURES Advisors in European countries and regions. This tends to be for less skilled work and is limited to the EU. There are many examples of national platforms aimed at supporting employers in finding workers outside the national labour market. WorkinDenmark is one example of an internet portal that includes a job and CV bank for high skilled individuals, accessible for employers who are registered to access this service.

82. For settlement countries with an annual target of economic migrants and an excess supply of eligible candidates, the challenge has been to ensure that those with a job offer in hand, or those with urgently sought skills, don't end up in a backlog. One response has been the development, in Australia, of "SkillSelect". Introduced in 2012, SkillSelect is an electronic system that enables skilled workers (and

\footnotetext{
${ }^{14}$ In this document, "settlement countries" refers to Australia, Canada, New Zealand and the United States.
} 
business people) interested in migrating to Australia to record their details to be considered for a skilled visa through an Expression of Interest (OECD 2014a). Australian employers can consult these details (as can state and territory governments) and nominate aspirant migrants for skilled visas. They are then invited by the Australian Government to lodge a visa application.

83. The Canadian Express Entry system launched in January 2015 has similar functionality, with employers able to identify and choose skilled migrants from an electronic Job Bank. Not only does the system prioritise candidates sponsored by an employer, it also accelerates the processing time. In the case of Australia, those offered employment in any of the skilled occupations list are exempt from the labour market test, further accelerating the process. Applicants still need to have gone through the necessary processes to demonstrate their skill levels or language proficiency. The major advantage to employers is that essentially this system enables them to hire migrants knowing they are pre-approved for meeting immigration and skill standards.

84. These are all new systems with little information on the effectiveness of such matching platforms. Generally, the extent to which public sector vacancy boards can cover the range of skills that SMEs might need requires more consideration.

85. In European countries, where almost all permits are issued only on the basis of a qualifying job offer, and there are no numerical limits on the number of skilled workers to admit (except for the United Kingdom and Greece), such a procedure is of less applicability for accelerating processing, although it remains a means to create a pool of candidates with interest in migration and who are ready to undertake recognition and certification procedures to qualify as skilled candidates.

86. SMEs, as noted above, may be less likely than large firms to invest in untested candidates, and undertake the administrative burden related to their immigration. They are thus likely to benefit disproportionately from policies which bring candidates to their doorsteps, so they can be met face to face and a trial employment period offered without having to sponsor a work permit application. Job-search visas are offered in different forms to qualifying candidates in a number of European countries: Austria, Denmark, Germany and the Netherlands. Candidates on such visas can make face-to-face contact with employers, and the conversion of the job-search permit to a work permit is generally facilitated.

87. Yet another means to increase the pool of third-country national candidates has been the opening up of post-study job search visas for international students that provide a limited duration of time (at least six months after graduation) to secure a qualifying job and continue their stay. Such extensions are offered in Austria, Denmark, Estonia, Finland, Germany, Italy, Netherlands, Norway, Poland, Sweden and Switzerland. Graduating international students are ideal candidates as during their studies they have generally acquired the local language and knowledge of local living and working conditions, and employers understand and acknowledge their qualifications.

\section{Employer sponsorship and accreditation}

88. Employers often face time-consuming administrative requirements in order to hire third-country nationals from abroad. Pre-approval can accelerate these processes for employers who meet specific policy criteria for demonstrating employer capability to responsibly recruit and manage overseas workers. While workers have to meet requirements such as wage standards or skill levels, employers do not have to repeat documentation relating, for example, to their business practices. Further, as discussed in the ICT section, many member countries have procedures where employers can be expressly recognised for the purpose of gaining simplified procedures including reduced evidentiary needs as well as fast-tracked processing. 
89. There are advantages to acquiring such employer status. In Australia and New Zealand, employers who are pre-approved to recruit migrant workers are LMT-exempt. In the U.K., sponsors (holding an A-rating) can exempt certain temporary workers (Tier-5) from demonstrating evidence of maintenance funds by certifying that they will not claim public funds during their stay. The U.K. also allows these employers to pay an additional fee and receive individualised service from the migration authorities. Working for an accredited employer in New Zealand provides a Talent Visa for a skilled migrant with a pathway to residence ${ }^{15}$.

90. These sponsorship and accreditation systems tend to penalise SMEs which hire few workers from abroad, as well as new firms without documented history. This is because criteria used for recognition include employers' past annual recruitment numbers, human resource and training systems, history of compliance with employment and immigration laws as well as efforts to recruit and train local workers. In addition, qualification for sponsorship may be restricted to major users of programmes. For instance in Australia, businesses should have a turnover of AUD 4 Million. In Sweden, certification occurs only if a minimum of 25 non-EU workers per year are required.

91. Examples where SMEs receive favourable treatment are rare. One case is Spain, where eligibility criteria for companies that can recruit highly qualified professionals specifically include Spanish SMEs that are considered to be "strategic"16 in nature. Sweden has indicated small concrete steps to make it easier for recruitment of labour from outside of the EU/EEA by introducing an extended and permanent certification system for employers (EMN Sweden 2013). The new system was to provide possibilities for smaller businesses to become certified. The requirement for a hiring demand of at least 50 persons has been lowered to 25 and the certification, which has so far been applicable for one year at a time, will no longer have a time limit.

\section{Information dissemination}

92. The lack of awareness about where to access information and the limited range of accessible user-friendly information may be significant barriers in themselves. While most countries provide basic information for employers on authorisation of foreign workers, there are several examples of well provisioned information resources and toolkits specifically for employers. One SME-specific example is an initiative launched in 2014 by the UK Visas \& Immigration in partnership with the Greater London Authority ${ }^{17}$. This 3 month pilot was launched to specifically provide online support to SMEs which need to recruit skilled international employees to help build their business. The dedicated website has a toolkit that includes a simple overview of the process of sponsoring an overseas worker, a best practice guide and some frequently asked questions, with access to expert help from the Home Office for complex queries. Increasingly, immigration agency website post information specifically for employers on their migrant worker solutions and practical information such as processing times and fees as well.

\section{Outreach}

93. Integrating labour migration into human resource strategies is usually expected to be the initiative of employers. Not all employers do so, and outreach initiatives may help bring this possibility to the

15 New Zealand has an Approval in Principle (AIP) channel for employers of less skilled workers that help with clearing a labour market test beforehand.

16 Article 71(a)(5) of Law 14/2013

17 https://www.rec.uk.com/news-and-policy/press-releases/home-office-provides-support-for-smes-recruitinginternational-talent 
attention of employers. An example is Japan, where employer reluctance to recruit from abroad even in the face of a shrinking working-age population and a tight labour market has frustrated government attempts to reach a modest target for high-skilled immigration. The government organises training sessions for employers on how to recruit foreign workers and integrate them into their workforces. Even in Australia, where economic migrants are a significant share of labour market entries and employers are accustomed to hiring foreign workers, there is an Australian Outreach Officers Network. The Network targets three different stakeholder groups - regions, industries and national unions. Outreach Officers are seconded specifically to these groups to provide information about skilled migration recruitment, immigration options for managing skill shortages, and employer obligations and migrant worker rights. Outreach officers meet with senior representatives from industry organisations, providing information about skilled migration to employers and presenting information on skilled visa options to students, write articles for a variety of trade media outlets and work closely with departmental colleagues to help improve processes and/or resolve problems.

\section{Integrating workers at the workplace and in the community}

94. The human resource departments of large companies often offer support to their international recruits and their families, support which can tax the limited resources and experience of SMEs. Mainstream services that make it easier for new labour migrants to settle in can thus take some of the burden off SMEs. One-stop shops connect migrants to the many non-migration services that they may need under one roof, so that employers can simply refer labour migrants to this centre. Portugal's High Commission for Immigration and Intercultural Dialogue (ACIDI) connects migrants to permits services, the police, healthcare, schools, and other services. WorkinDenmark, by contrast, provides a hotline service and, more importantly, a single point of contact for both employers and migrants that supplies information on residence permits, social security numbers, health insurance cards, authorisations, taxation, etc. The same tax-payer funded service also assists migrants with settlement, job seeking for spouses, and facilitating the return home when stays are temporary. Retention of workers is a challenge especially for smaller firms and in this regard, the need for post-placement or post-hire support especially in the early months of settlement has been suggested (Allies 2012).

\section{Other hiring support programmes}

95. A key challenge to international recruitment by SMEs is the hiring cost involved. Financial support is rarely provided for hiring from outside the EU/EEA. The EURES and institutions like ZAV have financially supported SMEs with less than 250 workers but this is limited to specific occupations like IT engineers, physicians and nurses and to member countries where bilateral agreements exist. Once conditions are met, financial support can take the form of travel and relocation subsidies as well as sponsored language and integration courses (Constant and Rinne, 2013).

96. SME focussed research in Canada (Allies 2012) showed that financial incentives, while contentious, can be helpful especially in the form of wage subsidies, tax credits or tax holidays. Canada has, for instance, a Hiring Credit for Small Business (HCSB) introduced in 2011 which provides employers tax credit up to CAD 1000 based on the increase in the amount of employment insurance (EI) premiums paid. This was meant to stimulate new employment and the study recommended extending this credit to new migrant hires as a way of helping SMEs. However, even if the question of subsidising recruitment of workers from outside Canada is resolved, this still leaves the SME with the task of identifying and enabling a temporary hire to arrive in Canada in the first place. 


\section{Discussion}

97. There are only a few examples of OECD countries offering labour migration instruments specifically targeting or favouring SMEs, even if they are in a weaker position relative to large employers and multinationals in terms of being able to use international recruitment channels. A first question that arises is whether admission criteria can be adjusted to compensate for the difficulty SME employers face when looking to employ migrant workers. It would appear admission criteria are determined by the needs of the labour market, which in turn identify the skills of the worker and the type of occupation, rather than the size of the firm. This raises two issues: first, the expected migrant labour needs of many SMEs often lie in the medium- or even low- skill segments, which are frequently not allowed under labour migration regulations. Second, even where foreign workers can be recruited, employers perceive an excessive administrative burden. While the first obstacle is difficult to address politically in the short term, the second is much simpler. There are mechanisms for easing the burden on SMEs, such as lowering fees, or providing assistance in accessing facilitations such as pre-approval, accreditation and trusted sponsorship.

98. Outside of migration policy, however, other tools can be more influential in helping SMEs identify, recruit, settle and retain foreign workers.

99. Large employers can avail of a recognised sponsor status and simplify procedures. Even where they are availing fast-tracked processes, they do have to pay for such services. Employer approval or accreditation represents a sunk administrative cost - and often fees - though its subsequent benefits make it attractive for employers. This raises the possibility that a recruitment firm may gain such status and this may well pave the way for smaller firms to avail of such advantages. The emergence of certified companies in Sweden, to submit applications on behalf of other employers, is a new segment of businessto-business services. More than 500 employers including SMEs used their services in 2013 (National Trade Board 2015). Another example is an employers' cooperative where a number of small employers group together to form a single entity thus considerably helping reduce average administrative costs. In all these instances, there is the issue of maintaining balance between reducing costs for employers who cannot meet skill needs locally while ensuring that some sort of cost wedge remains in place to disincentivise foreign recruitment.

100. Governments can help with active recruitment approaches as with the virtual job matching services gaining traction in some of the settlement countries even if it is aimed at the high skilled. The example of the EURES Job Mobility Portal for workers from within the EU is another example which facilitates job matching. In practice, it is already visible to third country nationals, even if there is no targeting of specific skill demands or sectors that may be of importance to SMEs. This may be possible to consider widening to third countries on a limited or pilot scale for specific occupations where credentials recognition mechanisms are well established.

101. Employers identify need for support with early workplace settlement and integration especially as source countries grow more diverse and are dissimilar to their own. Even as this raises the contentious political issue of who should pay and bear these costs, there is the need to build on public policy support and the consensus for an investment approach.

102. There is scope to build on the existing suite of initiatives to support SMEs by extending it to migrant recruitment. For instance there is considerable support for SME through initiatives such as the 2008 Small Business Act (SBA) for Europe - a wide-ranging set of pro-enterprise measures designed to make life easier for small and medium size firms. None of these even mention labour migration and foreign workers. The Enterprise Europe Network and 'single point of contact' model for helping SMEs go truly international includes contact points in third countries that can be considered for including migration aspects. Further, the European Commission is working with the Member States to make fully-fledged, 
user-friendly eGovernment portals, so that start-ups and established businesses can spend less time on administrative procedures. Also, implementing a 'once only' principle will mean that businesses do not have to submit the same data several times to different government bodies for licensing, tax or statistical purposes. Is there anything in these networks here that SMEs can tap for the management of human resources especially to recruit international skills?

103. Finally, even where measures have been put in place the outcomes can be mixed. The reform in Sweden has increased the number of small firms hiring labour migrants, and increased the number of firms using the system to apply for small numbers of workers (OECD, 2011a). However, in this case it reflects in part the greater number of "ethnic" restaurants recruiting migrants. It is less clear if small businesses outside the hospitality sector are able to access recruitment and if small businesses owned by Swedish employers without access to an immigrant network are equally able to find workers abroad. And even where countries use mechanisms such as the sponsorship approach, it is no guarantee of better outcomes. Where the LMT process is well established and easy to manage, pre-approval may not represent an efficiency gain.

\section{Recommendations}

- Lack of access to information on immigration requirements could be a major barrier in itself and therefore to consider improving information dissemination. To also consider including where appropriate dedicated arrangements for outreach to key industries and stakeholders as well as intermediaries such as accountants or sector councils.

- Job matching is a crucial element in the recruitment process and SMEs can benefit from both clearinghouse-type skill hubs for identifying local resources and migrant workers as well as sophisticated electronic job banks where employers can choose workers who are pre-approved for immigration. At the EU level, consider extending EURES for limited or targeted recruitment of third country nationals on a pilot basis.

- Explicitly provide options for SMEs to consider gaining recognised status through third party or co-operative type arrangements to overcome disadvantage of size and scale.

- At the national level, Leverage existing arrangements under Small Business Acts (e.g.eGovernment portals) to reduce duplication of paperwork for SMEs associated with migrant recruitment processes as well as extend scope of SBA internationalisation efforts for migration.

- Increase provision for settlement support such as work place communication skills besides vocation-specific language training.

\section{Attracting entrepreneurs and investors in the EU single market}

104. The above sections focused on skilled migrants brought to Europe by employers under the prevailing demand-driven systems. One important category of skilled migrant, however, cannot be brought by an employer: the investor or entrepreneur.

105. To the extent that investor programmes take into account human capital, and not just financial capital, they are a channel for skilled migration. Even in the absence of formal qualifications, entrepreneurial abilities can be a part of the human capital mix, the proxy being successful experience of running a business or generating commercially viable ideas. 
106. There has been increased interest in fostering investor migration especially since the global financial crisis of 2008. While the scale of investors annually coming into individual European countries never exceeds the thousands, in comparison to large flows of skilled migrants, the attention given to these programmes reflects the wide range of expectations from policy makers. Investors are expected to be agents for wider economic transformation - directly through the physical (financial) capital that they bring as well as through their business skills, experience and international networks. Many countries have programmes that admit business persons to undertake commercial activity that may well include investors. This chapter focusses on explicitly set up investor immigration programmes.

\section{Economic benefits of admitting investors}

107. Investors are mostly identified with generating two types of economic benefits production/innovation and consumption effects (MAC, 2014). High net-worth migrants who enter a host economy as investors should be able to ease capital constraints for domestic firms, stimulate knowledge spillovers between investors and recipients: for example, from skilled investors with sector-specific expertise to recipient firms' (cited in Nathan, 2014). Further, they are also known to play a role in facilitating trade and foreign direct investment (FDI) flows between host and home countries as well as helping domestic investors with 'home' market investment opportunities. On the other hand, rich investors and their families as residents can also be major consumers, creating demand for local goods and services such as high quality housing, domestic staff, luxury goods etc.

108. Much of this impact, however, will be contingent on local institutional settings, business practices and the level of information asymmetry. Consequently, the average impact of such investors (and their investments) can be nominal and much will depend on the volume and characteristics of such investor and investment inflows as well as the relative size of the overall host economy and financial markets.

\section{Global context for investor related interest}

109. The global millionaires club is increasing in numbers and increasingly in emerging markets as well. In 2012, the population of High Net Worth Individuals (HNWIs) ${ }^{18}$ grew by $9.2 \%$ over the previous year to reach 12 million individuals (Figure 4). At the same time, the wealth of HNWIs also grew substantially by $10 \%$. HNWI wealth is forecast to grow by $6.5 \%$ annually to US\$55.8 trillion by 2015 . North America remains the largest HNWI market but Asia-Pacific, where the growth rate is fastest, is set to surpass North America. By definition, HNWIs are an attractive target segment for investor policies.

110. It is not necessary to be an HNWI to migrate as an investor to many OECD countries. For decades, investor programmes in traditional settlement countries have set much lower thresholds for participants. These programmes stand out for the range of policy objectives as well as admission criteria reflecting the varied approaches among countries, bidding to attract such investors. However, the current wave of interest has been spurred since the early 2000s and particularly after the 2008 financial crisis with the aim of helping revive economies in general, and housing markets in some countries. At present these programmes account for only around a few thousand annually among all countries, a small number compared to the twelve million HNWIs and many more less wealthy potential participants. The challenge for host countries is in identifying and attracting the right type of investor migrant for their specific objectives.

18 HNWIs are defined as those having investable assets of US\$1 million or more, excluding primary residence, collectibles, consumables, and consumer durables. 
Figure 4. High net worth individual population, 2007-12 (by region)

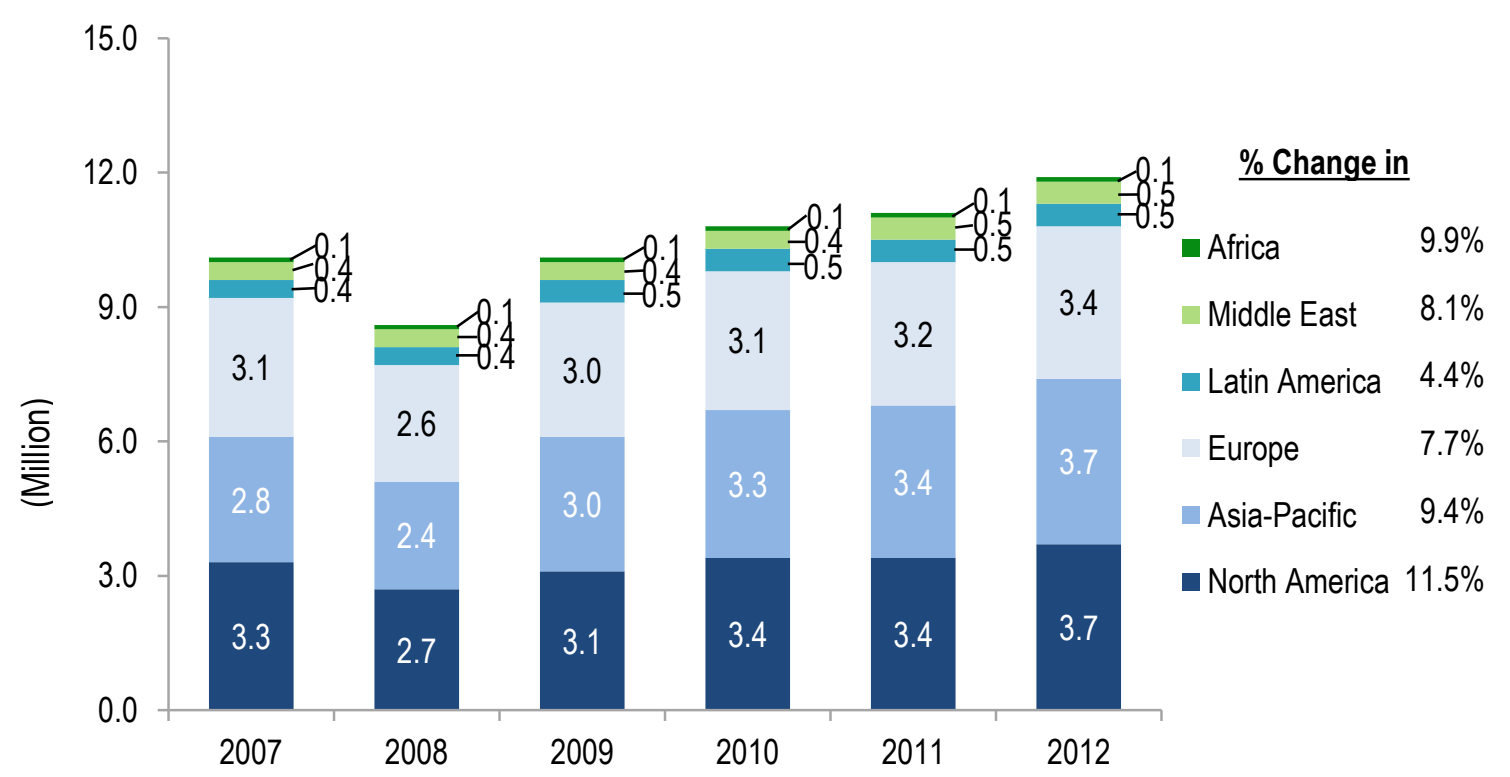

Note: Chart numbers and quoted percentages may not add up due to rounding.

Source: World Wealth Report, Capgemini Lorenz Curve Analysis, 2013-2013.

111. At the other end of the equation, migrants are motivated by a number of reasons to seek the investor migrant route. These include, but are not limited to, ease of setting up business, local supply of skills, language familiarity, proximity to markets, lifestyle choices, desire for a safe "bolt-hole" that is free of political and economic turmoil, superior education and health systems, the ability to travel visa-free and in some cases to avail of free mobility privileges. UK investors identified the British education system as a key factor (MAC 2014), while a primary motive for New Zealand investors has been lifestyle (MBIE 2014). Some investor programmes are in the border-free Schengen zone, while others, such as Romania and Bulgaria are candidates although investors might consider inclusion foregone.

\section{What is the policy rationale for investor programmes?}

112. Governments advertise a range of economic objectives that include creating infrastructure, investment for innovation, growth employment generation when positioning themselves as destinations of choice for investors. The policy logic behind the stated high level objectives are seldom well articulated in terms of what economic benefits are expected to accrue and how this will occur. However, the main policies to date can be broadly grouped into four categories in terms of motives.

113. In the first instance, migrant investment has been sought as a channel for low-cost investment capital at extremely low interest or even no interest. In Quebec, for example, an investment of CAN \$ 800 000 in the Quebec investor programmes ${ }^{19}$ is managed by the province in a way the province deems fit for local economic development and returned to the investor at the end of 5 years - without any interest.

19

Canadian federal investor program was closed in February 2014 and replaced in 2015 with a pilot program. 
114. A second factor is support for generating employment or business formation or development either through new or existing businesses. Investors are required to place EUR 1 million in fixed deposits in Spanish companies - EUR 1.25 million in the case of Netherlands - into government directed avenues including venture capital funds. Some countries specify the number of jobs expected to be created Portugal, Romania and the U.S. (10 jobs) and Bulgaria (5). Job requirements can vary by the type of investments. In Romania 10 jobs must be generated if the investment is in a limited liability company and 15 jobs if it is in a joint stock company. Under the EB-5 program in the USA, 5 jobs is the minimum where the investment is directly into a commercial activity or 10 if indirectly invested through a regional centre, an entity that channels investment into local economic development. In France, a 10 million euro investment in commercial or industrial assets qualifies for investment and the investment may be personal or through a company in which the investor owns at least $30 \%$ of the capital.

115. A third and recent motive has been to support and revive the housing market by way of residential property ownership or development as in Greece, Ireland, Korea, Latvia, Portugal and Spain. Of the required EUR $1 \mathrm{M}$ investment in Ireland, 50\% could be invested in personal dwelling but matched with $50 \%$ investment in real estate including residential investment property ${ }^{20}$. New Zealand allows property development but prohibits buying into existing stock and Australia permits investment in property as long as it is an asset class within managed funds. On the other hand, the U.K. specifically prohibits investment in property investment, management or development.

116. Lastly, governments open doors for those who can finance infrastructure or government debt either through endowment funds or literally non-refundable cash donations. Ireland accepts such donations provided it is "visible to the Public and of benefit to the wider community". Spain allows investors to place EUR $2 \mathrm{M}$ in Spanish public bonds as part of public debt to finance parks, infrastructure etc., although the government will return this at the end of the lock-in period. Most investors in the U.K. preferred to purchase gilts that had a 3\% nominal return although real returns could be zero (MAC 2014). Irish investment bonds designated for such investors yielded a $0 \%$ return.

Figure 5. Investor policy rationale

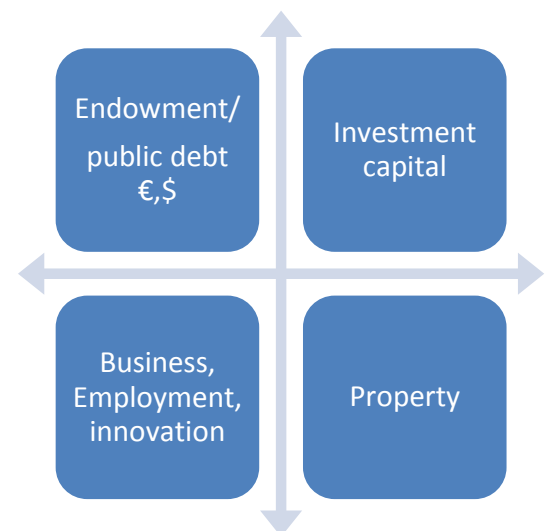

Note: The investment options are occasionally offered in a way that applicants can choose more than one option or even pool funds with other applicants to meet the threshold limit. In Ireland mixed investment is possible.

$20 \quad$ NZ allows property development but not buying into existing stock and Australia permits investment in property as an asset class within managed funds. 


\section{Criteria for gaining admission}

117. Besides the varying rationale and multitude of investment options for such investor programmes, the policy criteria for admission also show considerable variation. Financial capital is the main threshold. The minimum investment can be very high, as much as 10 million euros in the case of France, or as accessible as the100 000 euros investment in Romania (Figure 6). Latvia until recently was the lowest, requiring around 70000 euros investment in real estate. Excluding the settlement countries, and the outlier France, the average across these countries is around 500000 euros. Most countries conduct due diligence on the source of the funds, in some cases including using specialised audit firms, to establish if the money has been gained legally and is untainted. It can be difficult to assess the source of wealth for wealthy strangers from countries with unfamiliar legal and political systems.

Figure 6. Investment thresholds, Euros, 2015 (log scale)

\section{Investment threshold}

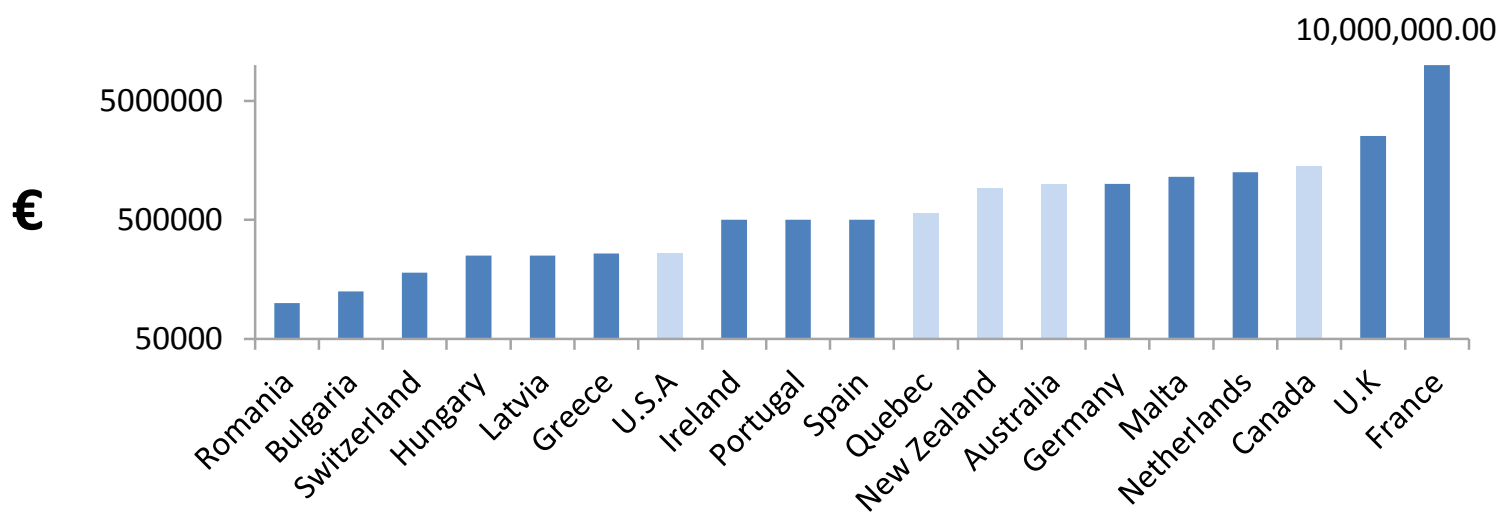

Note: Countries have several investment options on offer and the lower value thresholds are indicated here and does not distinguish by the type of investment e.g. endowment fund, property. France has the highest threshold of Euro 10 million. Canada closed its federal investor programme in 2014 and replaced it with a pilot program in 2015.

118. Besides assessing the investment thresholds for different investment options (where applicable), in some cases scrutiny is made of the business investment plans to determine if it meets the definitions of strategic or innovative areas as in the Netherlands, Australia or the United States. For instance, an investor's business plan for the Netherlands should have an analysis of the market, organization, and mode of financing; and how it would add value to the Dutch economy through innovation, creation of working places and investment. In the US EB-5 program, assessment will be done to see if the investment aligns with the business plan of the US regional centre.

119. Most countries do not set too much store on the characteristics of the investors, especially compared with the selection of skilled migrants, when the education and occupation of the individual is carefully examined. Wealth seems to be a sufficient criterion on its own. In fact, few countries have specified human capital attributes such as education, language, adaptability, business experience or maximum age. As part of the effort to recognise factors that help with adaptability and settlement, previous time spent in the country is acknowledged in some places. For this reason the UK reduces the investment threshold and the level of assets required. For instance, where an applicant has lived for 5 years in the UK, they can invest at the minimum threshold, and this investment increases if lesser years were spent. 
120. Besides these, the standard requirements cover demonstrating self-sufficiency and committing to non-entitlement of access to public services for applicant and dependants as well as proof that applicants are free of criminal convictions and are in good standing.

\section{Residence requirements}

121. Both temporary and permanent residence options are provided to attract investors. A key attraction or even return for investors, however, is the right to permanent residence and the subsequent pathways to naturalisation for both principal applicants as well as dependents. In this context, the residence rules reflect the objectives of the policy for any given country as to what they seek from their investors their money, their skills, or both. Most of the countries offering investor permits also offer work permit schemes for business managers, which however require the individual to reside in the country. The investor permit, by contrast, may allow "global high flyers" to avoid staying in the country of investment for extended periods. Yet in the case of active investment, forging local links and understanding local markets requires some meaningful time in the destination country. Striking a balance thus becomes tricky.

122. Examples of solutions range. Foreign investors can maintain their resident status in Hungary without visiting the country, and investor programs in Spain, Latvia, Portugal, and Ireland only require one visit per year. Portugal requires 7 days in the first year followed by 14 in subsequent years. In the case of Latvia, even one day will count. Three countries - Bulgaria, Malta and Romania - provide a permanent residence permit immediately to an investor. Canada was the only non-European country to provide this. The settlement countries tend to impose higher stay requirements in terms of the number of days for every year required but even here the limits are being revised for different investment levels. For instance, in Australia the new premium investor policy (AUD 15 Million) under development ${ }^{21}$, the applicant may not be required to stay in the country at all while the significant investor category (AUD 5 Million) requires 160 days stay over four years. In 2011, the U.K. relaxed requirements for stay duration outside the country by doubling the limit to 180 days from 90 .

123. Residence permits in Europe are renewable every one or two years initially or in the case of Australia and New Zealand, the provisional residence is valid for four years. Permanent residence is, however, granted subject to fulfilling investment related requirements for the mandated period which is mostly locking in the investment amount for around 4-5 years. In Canada, before the federal investor programme was scrapped in early 2014, the right of permanent residence was available immediately from the time of arrival; Quebec still retains this. The new premium investor route, mentioned before, in Australia is considering a shorter time of 12 months to permanent residency. A specific recommendation of the MAC review of the investor route was that increased thresholds should be incentivised with faster pathways to settlement.

124. Permanent residence usually paves the way for gaining citizenship via naturalisation. Increasingly even here, fast track options are beginning to be offered as in the case of permanent residence. Bulgaria and Malta adopt a formal residence requirement of one year, but the investor is not required to actually stay in the country during this period. Malta in 2013 introduced its investor programme which provided immediate citizenship subject to investing the required amount which was later changed to demonstrate the residence requirement of a 'genuine link' with Malta during that period. In Bulgaria, the investment of specific amounts in government bonds and making a commitment to maintain those investments for a period of at least two years after acquiring permanent residency, entitles an applicant to acquisition of Bulgarian citizenship within two years rather than the usual 5 years. For Tier-1 investors in

21 http://www.minister.immi.gov.au/media/sm/2014/sm218547.htm 
the UK, a fast tracked option for early settlement provides citizenship eligibility with just two years of permanent residence.

\section{Investor policy trends and developments}

124. In the EU, the adoption of investment migration policy has been a relatively recent phenomenon. The UK tier-1 investor route introduced in 2008 has similarities to the investor policies of the settlement countries that have had experience for a few decades. In the countries where the policy has been established for a while, there have been regular changes over time to the parameters.

125. Specifically, there has been constant balancing of the investment thresholds and the human capital criteria with the tendency to have fewer requirements around age, language levels and stay duration that has now come to have an almost inverse relationship to increasing investment amounts. For instance, in Bulgaria previous requirements concerning language competence and relinquishment of current citizenship were eliminated by recent changes in legislation. Another recent development has been the use of the Points Based System (e.g. standardised criteria), primarily used for selecting skilled economic migrants, being extended to investors, with a view to sort the ideal combination of investment and human capita criteria as in the U.K. and the Netherlands. It is for example possible to receive points for investing in Dutch growth industries . Besides the Points Based System, the use of an Expression of Interest (EoI) system (OECD 2014a) means that only those invited can expect to have their visa processed. This EoI system is currently in place only for some investor programmes in Australia and New Zealand.

126. Besides creating different tiers or levels of investments to target different types of investors, steering investments into active or passive investments has been one consideration for policy makers. For instance, EB-5 investors in the US can invest in a new commercial enterprise or one affiliated to a US regional centre, an entity recognised for local economic development. The US Regional centers make no guarantees on the investment, or that sufficient estimated job creation will be realized and credited to the immigrant investor. If it is determined by the assessing agency that the investor's money is not truly at risk, then the investor's petition may be denied. While recognising that active investments are preferable, not many countries actually provide incentives for making such investments. Most penalise investors if there is any drop in the value of the investment at the set review periods. Such an approach reduces risk taking and shepherds most investors to park their investments where there is the least risk. In the UK, for most Tier 1 investors, the return on their investment is less important than its stability, as this will more easily enable them to meet the requirements of the route for entry, residence and settlement. ${ }^{22}$ Hence UK investors prefer buying bonds or gilts to buying share capital.

127. As for numbers flowing through this channel, the more established programmes had numbers ranging in the thousands. In 2013, the US EB-5 programme had reached 7312. Likewise Canada had 3618 (2012), Australia 2475 (2013/14) and the U.K 2425 (in 2013) $)^{23}$ - in all cases these included investors and their families. On the other hand, more recent entrant to the investor programme saw modest numbers. For instance, Austria had 29 (in 2011) and Greece, based on pre 2014 laws, had issued 205 permits for investments of euro 60000 and over. Up to 2014, Portugal had issued 734 Golden visas mainly to Chinese nationals. The Netherlands had no investor migrants in 2013.

128. With increasing concern over cases of fraud, tainted money and public opinion, numerical controls have been introduced or contemplated especially for investor categories with lower investment thresholds as in Latvia, Portugal, Malta and Romania. In the US, the EB-5 investor programme has both an

\footnotetext{
$22 \quad$ Keeping this in view, Australia and New Zealand changed their programmes so that investors are not penalized if the original value of the investment reduces due to the market at work.

23

included in-country and those applying from out of the country
} 
overall ceiling of 10000 and quotas to prevent any one nationality from being overrepresented on the programme. The EB-5 immigrant visa quota for China has been exhausted for Fiscal Year 2014.

\section{Discussion}

129. While countries and investors have a range of motives, aligning the two is not easy and it has been commented that investment and migration are intrinsically two different logics and combining the two can distort market decisions (Nash, 1996).

130. It is not hard to fathom what most motivates investor migrants. Investors may treat investments as a sunk cost, especially but not only where there is an outright non-refundable donation or as a foregone opportunity cost. Further, given a choice between visas with similar benefits, investors pick the cheapest options or the least risky path of resistance. In Latvia during 2012, foreigners applying for the investor visa mostly chose to purchase real estate rather than investing in the fixed capital of Latvian companies. In the U.K., most investors chose to invest in gilts, as it was a safe investment even if real returns were negligible.

131. Many investors would be eligible for visas as skilled migrants or as managers of their own businesses. Where the investment climate is favourable, even visas with few benefits - such as the lowthreshold treaty trader temporary visa offered by the US - attract large numbers of participants. If this is the case, then governments need to rethink how best to maximise the real economic benefits of using such investor routes. In this regard, the UK Migration Advisory Committee review (2014) has suggested using an economic policy instrument seldom used in migration policy. The review suggested the auctioning of fixed number of investor places after setting a reserve price - with all excess above this reserve being allocated to a public cause. This was deemed as both transparent and efficient even though auctions in themselves may not be perfect solutions (OECD 2009).

132. Policy makers will not only have to consider the type of investor visa appropriate for their objectives, but also take into account a cost-benefit analysis of a number of factors. Firstly, investor policy has to deal with the high cost of public perception that visas is about giving away or selling nationality, or diluting the premium associated with residency and citizenship. This may in part have made countries think about imposing numerical limits besides stricter residency requirements. In the case of Maltese accelerated citizenship for investors in 2013, it raised several issues including national security, unfair competition and European citizenship and cooperation in nationality matters (Carrera, 2014) leading to intervention from the European Commission.

133. Secondly, there are reputational risks to contend with which requires due diligence to ensure no money laundering or tainted money is involved and this involves resource intensity in the form of trained staff and trusted providers. Resource intensity also comes through related efforts at marketing a country as a "favoured destination". Further, deliberate strategies are required to foster connections between investors and local business and investment communities as arrival of investors and their money does not translate into automatic active investments. Finally, to also consider distributional impacts especially who gains in housing markets (e.g. housing sellers versus buyers) and externalities such as impact on neighbours as in free mobility areas. The latter was an issue for the EU when Malta first proposed its individual investor programme in 2013 with a speedy pathway to citizenship with no residency requirement.

134. Unlike other areas of economic migration, investor channel has had few systematic evaluations, and those which have been conducted have often found limited positive impact, leading to revision of programmes. For most part the focus of evaluation has been on process and service (e.g. take-up, connection to local groups), outputs (number of investors and investment volumes) and less to do with examining key outcomes (e.g. earnings/taxes, expanded output or improved jobs headcount). Some of this 
lack of monitoring may have to do with the way investors' investment is channelled and the general paucity of data. Canada, New Zealand and the UK have had reviews leading to programme modifications and even closure in the case of Canada.

135. In Canada ${ }^{24}$ research showed that immigrant investors pay less in taxes than other economic immigrants, are less likely to stay in Canada over the medium- to long-term and often lack the skills, including official language proficiency, to integrate as well as other immigrants from the same countries." Over a 20-year career, an immigrant investor pays about $\$ 200,000$ less in income taxes than a federal skilled worker and almost $\$ 100,000$ less in taxes than one live-in caregiver. Likewise, the UK review (MAC 2014) points that investors being able to borrow money for investment from UK registered financial institutions provides little or no value to the UK economy as it is simply a transfer of funds between two actors within the UK economy, rather than an investment of new funds. The UK capital market was working well and the annual aggregate loan via the investor route is equivalent to less than two days of the UK's budget deficit.

136. From the perspective of governments, the interest is not simply in attracting rich people. There are usually other "rich people visas", such as elective residence or retirement visas, mostly outside of the EU although these usually don't grant work rights, family reunification or a path to citizenship. Settlement countries often have more restrictive elective residence criteria than European countries. For example, Australia has an explicit retirement investor visa (designated investment of AUD 750000 or in regional Australia for AUD 500 000) which is a temporary visa to spend part of retirement years in Australia.

137. In a reversal of priorities, at times it is equally important to attract human capital in order to retain financial capital already in the country. The Start-Up Chile involves providing a US\$ 40000 nonrepayable grant to up to 100 entrepreneurs per year from all over the world selected by a "Silicon Valley" panel and the Chilean innovation board. Both Canada and Australia have initiated Start-up visas that place emphasis on the applicant being able to convince local venture capital funders into backing their business idea all the way through early phase start-up, product commercialization or business development and expansion. The UK Tier 1 (entrepreneur) visa is available for individuals who (besides meeting other criteria) can successfully obtain funds from a recognised UK venture capital firm or UK entrepreneurial seed funding competition.

\section{Recommendations}

- Use investor policy to signal intent that the country is open for business and has a range of economic migration channels.

- Structure investor policies to be clear on specific economic objectives rather than catch-all goals, and make trade-offs such as: balancing quality with quantity or human capital and financial capital as well as considering desired spill-over benefits.

- Improve systematic evaluations and assessment of cost-benefits including reputational risks, distributional impacts and externalities. 


\section{BIBLIOGRAPHY}

Allies (2012) Global Talent for SMEs - Building bridges and making connections, Toronto, Canada. http://alliescanada.ca/wp-content/uploads/2010/05/SMEs-Report-English1.pdf

Buschfeld D., B. Dilger, L.S. Heß, K. Schmid, and E. Voss (2011), "Future skills needs in micro and craft (-type) enterprises up to 2020"for the EC (DG Enterprise and Industry)", http://ec.europa.eu/enterprise/policies/sme/promotingentrepreneurship/files/skillsneeds_final_report_final_180211_en.pdf

Bahrke M. M. Demary K.Lichtblau and T. Schleiermacher (2011), Internationalisierung und Fachkräftesicherung. Eine Studie im Auftrag des Verbandes der Metall- und Elektroindustrie BadenWürttemberg e.V. Köln and Stuttgart: Südwestmetall.

Capgemini and RBC (2013) Global Wealth Report, Canada

Carrera, S (2014) How much does EU citizenship cost? The Maltese citizenship-for-sale affair: A breakthrough for sincere cooperation in citizenship of the union? CEPS paper in Liberty and Security in Europe, No.64/April 2014, Brussels

Cernat, L, A Norman-Lopez and A D T-Figueras (2014), "SMEs are more important than you think! Challenges and Opportunities for EU exporting SMEs", Chief Economist Note no. 3, DG TRADE, Brussels.

Constant, A.F and Rinne, U (2013), Labour Market Information for Migrants and Employers: The Case of Germany, I Z A Research Report No. 50, Bonn, Germanywww.iza.org/en/webcontent/publications/reports/report_pdfs/iza_report_50.pdf

European Commission (2010) Impact Assessment accompanying the proposal for a directive of the European parliament and the council on conditions of entry and residence of third country nationals in the framework of an intra-corporate transfer, $\{\operatorname{COM}(2010) 378$ final $\}\{\operatorname{SEC}(2010) 885\}$

European Commission (2011a)Council adopts intra-corporate transferees directive, Presse 65, Brussels

European Commission (2011b) Study on the economic and social effects associated with the phenomenon of posting of workers in the EU, Final report VT/2009/062, Brussels

European Commission (2011c) Key figures on European business with a special feature on SMEs, Luxembourg: Publications Office of the European Union

Lazarowicz, A (2013) The Intra-Corporate Transferees Directive: time to break the deadlock, European Policy Centre, Brussels

MBIE (2014), Investor Migrant Research 2013/2014 - Summary of findings, New Zealand http://www.dol.govt.nz/research/migration/pdfs/investor-research-migrant-20132014.pdf 
Migration Advisory Committee (2014) Tier 1 (investor) route - Investment thresholds and economic benefits, London

Nash, A (1996) The Economic Impact of Canada's Business Immigration Program: a Critical Reappraisal of Theory and Practice, Paper presented to the symposium on Immigration and Integration, University of Manitoba

Nathan, M (2014) The wider economic impacts of high-skilled migrants: a survey of the literature for receiving countries, IZA Journal of Migration 2014, 3:4, http://www.izajom.com/content/3/1/4

National Trade Board (2015) Trade Costs of Visas and Work Permits: A Trade Facilitation Perspective on Movement of Persons, Kommerskollegium Stockholm

OECD (2014a), International Migration Outlook 2014, OECD Publishing, Paris. DOI: http://dx.doi.org/10.1787/migr_outlook-2014-en

OECD (2014b), Recruiting Immigrant Workers: Austria 2014, OECD Publishing, Paris. DOI: http://dx.doi.org/10.1787/9789264226050-en

OECD (2014c), Recruiting Immigrant Workers: Norway 2014, OECD Publishing, Paris. DOI: http://dx.doi.org/10.1787/9789264226135-en

OECD (2013), Recruiting Immigrant Workers: Germany 2013, OECD Publishing, Paris, http://dx.doi.org /10.1787/9789264189034-en.

OECD (2011a), "Evaluating the new Swedish labour migration policy", in Recruiting Immigrant Workers: Sweden 2011, OECD Publishing. http://dx.doi.org/10.1787/9789264167216-10-en

OECD (2011b), International Migration Outlook 2011, OECD Publishing, Paris.

DOI: http://dx.doi.org/10.1787/migr_outlook-2011-en

OECD (2010), "Entrepreneurship and Migrants", Report by the OECD Working Party on SMEs and Entrepreneurship, OECD.

OECD (2009), International Migration Outlook 2009, OECD Publishing, Paris, http://dx.doi.org/10.1787/migr_outlook-2009-en.

Pascouau, Y (2013) Intra-EU mobility of third-country nationals, State of play and prospects, European Policy Centre, Brussels

Rodriguez, N. (2004). 'Workers wanted' - Employer recruitment of immigrant labor. Work and Occupations, 31(4), 453-473.

Sweden Migration Board (2013) Attracting highly qualified and qualified third-country nationals to Sweden: Report from EMN Sweden - http://ec.europa.eu/dgs/home-affairs/what-wedo/networks/european_migration_network/reports/docs/emnstudies/attracting/26.sweden_national_report_attracting_highly_qualified_final_october2013_en.pdf

UNCTAD (2013) World Investment Report 2013, Switzerland 


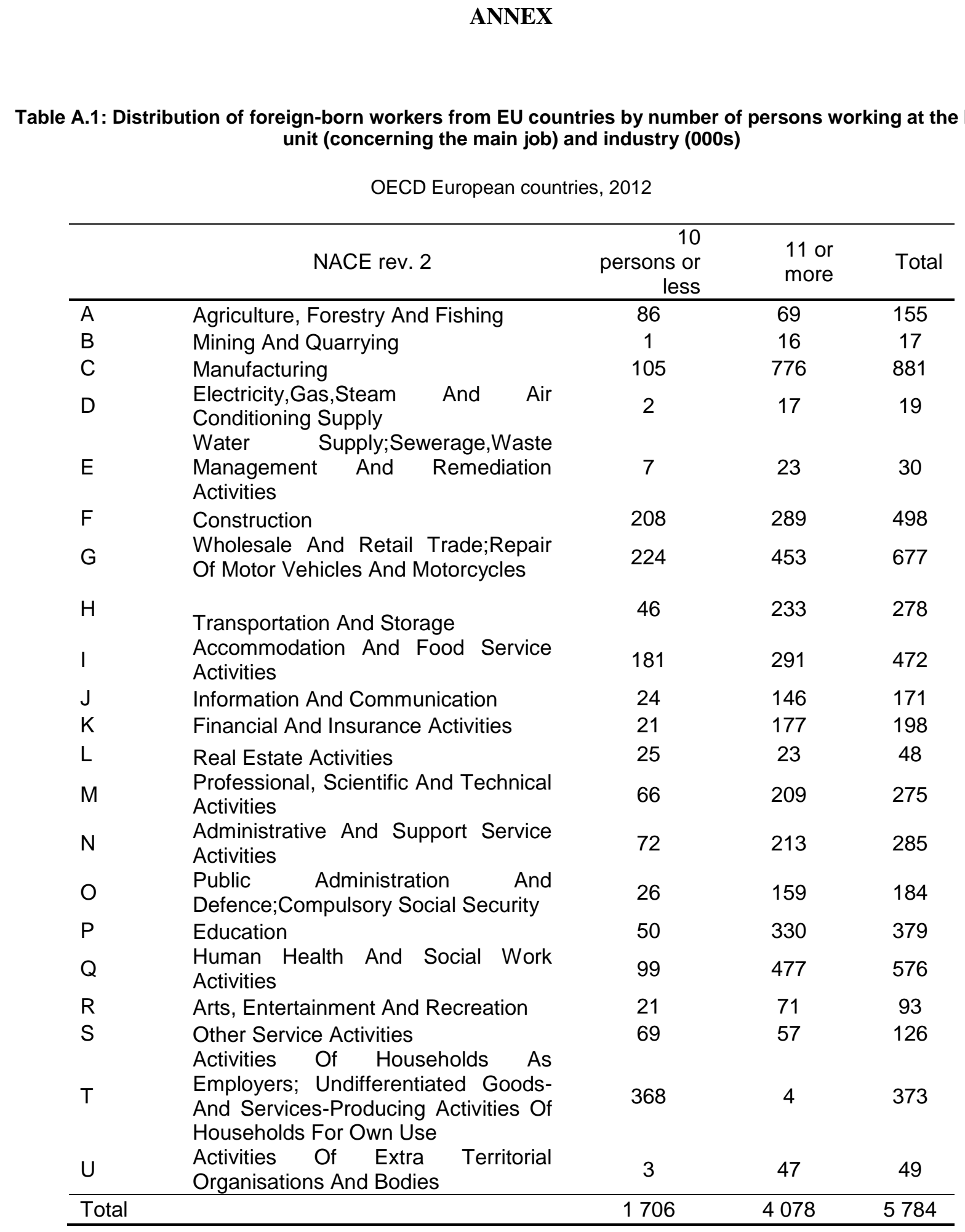

Source: European Labour Force Surveys (Eurostat).Note: The data excludes Germany because no information on the country of birth is available. 
Table A.2 : Distribution of foreign-born from non-EU countries workers by number of persons working at the local unit (concerning the main job) and industry (000s)

OECD European countries, 2012

\begin{tabular}{|c|c|c|c|c|}
\hline & & 10 & & \\
\hline & NACE rev. 2 & $\begin{array}{r}\text { persons or } \\
\text { less }\end{array}$ & 11 or more & Total \\
\hline A & $\begin{array}{lll}\text { Agriculture, } & \text { Forestry } & \text { And } \\
\text { Fishing } & \end{array}$ & 139 & 119 & 258 \\
\hline B & Mining And Quarrying & 4 & 17 & 21 \\
\hline C & Manufacturing & 209 & 1090 & 1299 \\
\hline D & $\begin{array}{l}\text { Electricity,Gas,Steam And Air } \\
\text { Conditioning Supply } \\
\text { Water Supply; Sewerage,Waste }\end{array}$ & 3 & 28 & 31 \\
\hline $\mathrm{E}$ & $\begin{array}{l}\text { Management And Remediation } \\
\text { Activities }\end{array}$ & 14 & 61 & 76 \\
\hline $\mathrm{F}$ & $\begin{array}{l}\text { Construction } \\
\text { Wholesale And Retail Trade; }\end{array}$ & 298 & 377 & 676 \\
\hline G & $\begin{array}{l}\text { Repair Of Motor Vehicles And } \\
\text { Motorcycles }\end{array}$ & 484 & 758 & 1241 \\
\hline $\mathrm{H}$ & Transportation And Storage & 80 & 435 & 515 \\
\hline I & $\begin{array}{l}\text { Accommodation } \\
\text { Service Activities }\end{array}$ & 514 & 534 & 1048 \\
\hline$J$ & $\begin{array}{l}\text { Information } \\
\text { Communication }\end{array}$ & 50 & 223 & 274 \\
\hline K & $\begin{array}{l}\text { Financial And Insurance } \\
\text { Activities }\end{array}$ & 37 & 220 & 258 \\
\hline L & Real Estate Activities & 33 & 41 & 74 \\
\hline M & $\begin{array}{l}\text { Professional, Scientific And } \\
\text { Technical Activities }\end{array}$ & 108 & 278 & 386 \\
\hline $\mathrm{N}$ & $\begin{array}{l}\text { Administrative And Support } \\
\text { Service Activities }\end{array}$ & 196 & 511 & 707 \\
\hline $\mathrm{O}$ & $\begin{array}{l}\text { Public Administration And } \\
\text { Defence; Compulsory Social } \\
\text { Security }\end{array}$ & 32 & 373 & 406 \\
\hline$P$ & Education & 58 & 523 & 581 \\
\hline Q & $\begin{array}{l}\text { Human Health And Social Work } \\
\text { Activities }\end{array}$ & 199 & 1091 & 1290 \\
\hline $\mathrm{R}$ & $\begin{array}{l}\text { Arts, Entertainment And } \\
\text { Recreation }\end{array}$ & 32 & 73 & 105 \\
\hline S & $\begin{array}{l}\text { Other Service Activities } \\
\text { Activities Of Households As } \\
\text { Employers; } \quad \text { Undifferentiated }\end{array}$ & 125 & 94 & 219 \\
\hline $\mathrm{T}$ & $\begin{array}{l}\text { Goods- And Services- } \\
\text { Producing Activities Of } \\
\text { Households For Own Use }\end{array}$ & 829 & 11 & 840 \\
\hline U & $\begin{array}{l}\text { Activities Of Extra Territorial } \\
\text { Organisations And Bodies }\end{array}$ & 11 & 39 & 50 \\
\hline Total & & 3458 & 6896 & $\begin{array}{r}10 \\
354\end{array}$ \\
\hline
\end{tabular}

Source: European Labour Force Surveys (Eurostat).Note: The data excludes Germany because no information on the country of birth is available 